\title{
Transcriptional Profiling of Newly Generated Dentate Granule Cells Using TU Tagging Reveals Pattern Shifts in Gene Expression during Circuit Integration ${ }^{1,2}$
}

\author{
Christina Chatzi," (D) Yingyu Zhang, ${ }^{*}$ Rongkun Shen, Gary L. Westbrook, and Richard H. Goodman
}

DOI:http://dx.doi.org/10.1523/ENEURO.0024-16.2016

Vollum Institute, Portland, Oregon 97239

\begin{abstract}
Despite representing only a small fraction of hippocampal granule cells, adult-generated newborn granule cells have been implicated in learning and memory (Aimone et al., 2011). Newborn granule cells undergo functional maturation and circuit integration over a period of weeks. However, it is difficult to assess the accompanying gene expression profiles in vivo with high spatial and temporal resolution using traditional methods. Here we used a novel method ["thiouracil (TU) tagging"] to map the profiles of nascent mRNAs in mouse immature newborn granule cells compared with mature granule cells. We targeted a nonmammalian uracil salvage enzyme, uracil phosphoribosyltransferase, to newborn neurons and mature granule cells using retroviral and lentiviral constructs, respectively. Subsequent injection of 4-TU tagged nascent RNAs for analysis by RNA sequencing. Several hundred genes were significantly enhanced in the retroviral dataset compared with the lentiviral dataset. We compared a selection of the enriched genes with steady-state levels of mRNAs using quantitative PCR. Ontology analysis revealed distinct patterns of nascent mRNA expression, with newly generated immature neurons showing enhanced expression for genes involved in synaptic function, and neural differentiation and development, as well as genes not previously associated with granule cell maturation. Surprisingly, the nascent mRNAs enriched in mature cells were related to energy homeostasis and metabolism, presumably indicative of the increased energy demands of synaptic transmission and their complex dendritic architecture. The high spatial and temporal resolution of our modified TU-tagging method provides a foundation for comparison with steady-state RNA analyses by traditional transcriptomic approaches in defining the functional roles of newborn neurons.
\end{abstract}

Key words: hippocampus; nascent RNAs; neural development; neurogenesis; transcriptome

\section{Significance Statement}

Unlike most regions of the brain, the hippocampus produces new neurons well into adulthood. These newborn neurons contribute to learning and memory, presumably because they functionally integrate into pre-existing circuits, whereas their decrease during aging may be associated with cognitive decline. This process occurs by dynamic regulation of many genes as these cells interact with their environment. We adapted an in vivo approach, providing both temporal and spatial control of gene expression that captures the transcriptional profiles of discrete populations of newborn neurons at distinct stages of their maturation. Our study provides insights into the underlying pathways controlling hippocampal newborn neuron differentiation and functional integration, which could lead to new approaches for enhancing their production, integration, and survival. 


\section{Introduction}

The subgranular zone (SGZ) of the adult hippocampal dentate gyrus (DG) is one of two neurogenic niches in the mammalian brain where new neurons are continuously generated throughout adulthood (Taupin and Gage, 2002; van Praag et al., 2002; Toni et al., 2008; Zhao et al., 2008). Adult-generated newborn hippocampal neurons ultimately integrate into pre-existing functional circuits, where, in mice as well as in humans, they may have specific roles in learning and memory (Gould et al., 1999; Clelland et al., 2009; Deng et al., 2010; Sahay et al., 2011). How newborn neurons are incorporated into an existing circuit is poorly understood and perhaps even more remarkable than their generation in the first place. Although the differentiation of newborn granule cell has been extensively analyzed (Overstreet-Wadiche and Westbrook, 2006), the patterns of gene expression underlying distinct stages of adult-generated newborn granule cell growth and maturation remain largely unknown. Studies of steady-state levels of mRNA in newborn neurons in vivo have been limited by the vast excess of other cell types and the dynamic changes in the phenotype of new neurons (Gould et al., 1999; Jagasia et al., 2009; Kuwabara et al., 2009; Mu et al., 2010; Fuentealba et al., 2012; Bracko et al., 2012). Thus, we lack an understanding of the dynamics of gene networks during adult newborn hippocampal neuron development, which requires in vivo approaches of mRNA expression that provide high temporal and spatial resolution.

The integration of newborn granule cells can be divided into a stage of immature neurons ( $\sim 2$ weeks postmitosis) and integrated mature neurons ( $\geq 4$ weeks postmitosis; van Praag et al., 2002; Overstreet-Wadiche and Westbrook, 2006). By 2 weeks postmitosis, adult-generated hippocampal granule cells have extended primary den-

Received February 2, 2016; accepted February 4, 2016; First published February 11, 2016.

${ }^{11}$ The authors declare no competing financial interests. ${ }^{2}$ Author contributions: C.C., G.Z., R.S., G.L.W., and R.H.G. designed research; C.C., G.Z., R.S., G.L.W., and R.H.G. performed research; C.C., G.Z., R.S., G.L.W., and R.H.G. contributed unpublished reagents/analytic tools; C.C., G.Z., R.S., G.L.W., and R.H.G. analyzed data; C.C., G.Z., R.S., G.L.W., and R.H.G. wrote the paper.

${ }^{23}$ This work was supported by National Institutes of Health Grant NS-080979 and the Ellison Medical Foundation (R.H.G. and G.L.W.); an AXA Research Fund fellowship (C.C.); and the National Institute of Neurological Disorders and Stroke Imaging Core Facility (Grant P30NS061800).

*G.C. and G.Z. contributed equally to this work.

R. Shen's present address: Department of Biology, The College at Brockport, SUNY, Brockport, NY 14420.

Acknowledgments: We thank the gene sequencing core at Oregon State for use of their facilities, Shannon McWeeney for assistance with bioinformatics, and Eric Washburn for initial production of viruses. The data were deposited in a MIAME-compliant database GEO, (http://www.ncbi.nlm.nih.gov/geo/query/ acc.cgi?token $=$ gzezcgyebfqxdsh\&acc $=$ GSE76587, GEO accession number: GSE76587)

Correspondence should be addressed to Gary L. Westbrook, Vollum Institute, L474, Oregon Health and Science University, 3181 SW Sam Jackson Park Road, Portland, OR 97239. E-mail: westbroo@ohsu.edu.

DOI:http://dx.doi.org/10.1523/ENEURO.0024-16.2016

Copyright (C) 2016 Chatzi et al.

This is an open-access article distributed under the terms of the Creative Commons Attribution 4.0 International, which permits unrestricted use, distribution and reproduction in any medium provided that the original work is properly attributed. drites into the inner molecular layer and nascent axons to stratum lucidum in CA3. These cells have the properties of immature neurons with broad action potentials mediated by $\mathrm{Na}^{+}$channels and receive spontaneous depolarizing GABAergic activity, but almost no excitatory glutamatergic synapses (Ge et al., 2006; Overstreet-Wadiche and Westbrook, 2006). Within the next week, they elaborate spiny dendrites that reach the middle and outer molecular layer, and begin to receive functional glutamatergic inputs from the entorhinal cortex such that surviving newborn neurons have nearly mature phenotypes by 4 weeks postmitosis (van Praag et al., 2002; Overstreet-Wadiche and Westbrook, 2006).

We hypothesized that the distinct stages of newborn neuron maturation are associated with characteristic patterns of gene expression. The convergence of stimuli that shape the integration of newborn neurons into functional networks implies the participation of many genes. Because many of these genes may turn over rapidly, this places a premium on understanding the cellular specificity, as well as the timing and sequence of gene expression. Measurements of steady-state mRNAs cannot easily resolve these issues. To address these issues, we used a novel viral-mediated thiouracil (TU)-tagging method (Miller et al., 2009), combined with RNA sequencing (RNAseq) to compare gene expression patterns of the small subset of adult-generated immature granule cells with mature granule cells in the adult dentate gyrus in vivo.

\section{Materials and Methods}

\section{Animal protocols}

All procedures were performed according to the $\mathrm{Na}$ tional Institutes of Health Guidelines for the Care and Use of Laboratory Animals, and were in compliance with approved institutional animal care and use committee (IACUC) protocols at Oregon Health \& Science University. Subjects were young adult, female, 6-week-old C57BL/6J mice (The Jackson Laboratory).

\section{Virus production and stereotaxic injections}

Moloney Murine Leukemia Virus-based retroviral vectors require cell mitosis for transduction, and were used to identify and manipulate adult-born granule cells. Uracil phosphoribosyltransferase (UPRT)-expressing retroviruses were created using a pSie-based viral backbone, and expression was driven by a ubiquitin promoter and followed by a woodchuck post-transcriptional regulatory element (van Praag et al., 2002; Tashiro et al., 2006). UPRT-expressing FUGW lentiviral vector was created as described (Lois et al., 2002; Luikart et al., 2011a). Mice were anesthetized using an isoflurane gas system (Veterinary Anesthesia Systems), placed in a Kopf stereotaxic frame fitted with a gas nose cone, and a skin incision was made and holes were drilled at $x( \pm 1.1 \mathrm{~mm}$ from bregma) and $y(-1.9 \mathrm{~mm}$ from bregma). Using a $10 \mu \mathrm{l}$ Hamilton syringe with a 30 gauge needle and the Quintessential Stereotaxic Injector (Stoelting), $2 \mu$ l of mixed viral stock (1 $\mu \mathrm{l}$ of each virus) was delivered at $0.25 \mu \mathrm{l} / \mathrm{min}$ at $z$-depths of 2.5 and $2.3 \mathrm{~mm}$. The syringe was left in place for $1 \mathrm{~min}$ 
after each injection before being withdrawn slowly. The skin above the injection site was closed using veterinary glue. Animals received postoperative lidocaine and drinking water containing children's Tylenol.

\section{Immunohistochemistry and quantitation}

Mice were terminally anesthetized according to IACUCapproved protocols, transcardially perfused with saline and $20 \mathrm{ml}$ of $4 \%$ paraformaldehyde, and brains were postfixed overnight. Coronal sections (100 $\mu \mathrm{m}$ thick) of the hippocampus were collected from each mouse and permeabilized in $0.4 \%$ Triton in PBS (PBST) for $30 \mathrm{~min}$. Sections were then blocked for 30 min with $5 \%$ horse serum in PBST and incubated overnight $\left(4^{\circ} \mathrm{C}\right)$ with primary antibody in $5 \%$ horse serum/PBST. The primary antibodies used were as follows: anti-doublecortin (DCX; 1:600; Millipore); anti-glial fibrillary acidic protein (GFAP; 1:1000; Dako); anti-Calbindin D-28K (1:500; Chemicon); antiNeuN (1:500; Sigma-Aldrich); anti-nestin (1:100; Chemicon), anti-CD68 (1:500; Abcam); and anti-Olig2 (1:300; Abcam). After extensive washing, sections were incubated with the appropriate secondary antibody conjugated with Alexa Fluor 488, 568, or 647 (Molecular Probes), for $2 \mathrm{~h}$ at room temperature. They were then washed in PBST ( $2 \times 10 \mathrm{~min})$ and mounted with DAPI Fluoromount-G (SouthernBiotech).

For quantification of immunopositive cells, six sections offering dorsal-to-ventral coverage of the dentate gyrus were stained from each animal. Three to five animals were analyzed for each time point and condition. Slides were coded and imaged by an investigator who was blinded to experimental condition with a Zeiss LSM780 confocal microscope under a $10 \times 0.45$ numerical aperture (NA), $20 \times$ or $40 \times 0.8 \mathrm{NA}$ lens. A $49 \mu \mathrm{m}$ z-stack (consisting of seven optical sections of $7 \mu \mathrm{m}$ thickness) was obtained from every slice. Positive cells were counted per field from every $z$-stack using ImageJ software, averaged per mouse, and the results were pooled to generate mean values.

\section{Nascent mRNA labeling and sequencing of dentate gyrus granular neurons}

Using a stereotaxic apparatus, $1.25 \mu \mathrm{l}$ of $1 \mathrm{~mm} 4-\mathrm{TU}$ (Sigma-Aldrich) was delivered intracerebroventricularly into the dorsal third ventricle $(-1.9 \mathrm{~mm}$ posterior to bregma, $\pm 0.0 \mathrm{~mm}$ lateral to midline, -2.25 ventral to the skull surface) at a rate of $0.1 \mu \mathrm{l} / \mathrm{min}$. Because in vitro preliminary data indicated that maximum TU incorporation peaked at $16-18 \mathrm{~h}$ (data not shown), dentate gyri from individual mice were harvested after overnight TU exposure and stored in $1 \mathrm{ml}$ of TRIzol. RNA was extracted using the RNeasy kit (Qiagen) with a modified protocol. Briefly, after tissue homogenization with TissueRuptor (Qiagen) in TRIzol, $200 \mu \mathrm{l}$ of chloroform was added to each sample and mixed thoroughly. Samples were spun down, and supernatants were transferred to new collection tubes. Five hundred microliters of $100 \%$ ethanol was then added to each sample, and tubes were inverted several times to mix samples well. The mixture was passed through an RNeasy column, and columns were washed two times with RPE buffer. Columns were dried by high-speed spin, and RNA was eluted with $80 \mu \mathrm{l}$ of water. Samples were then treated with DNAse I for $15 \mathrm{~min}$, processed using an RNeasy MinElute kit, and eluted in 13 $\mu \mathrm{l}$ of RNase-free $\mathrm{H}_{2} \mathrm{O}$. Samples were then heated to $65^{\circ}$ for $5 \mathrm{~min}$ and centrifuged at 12,000 rpm for $1 \mathrm{~min}$ and transferred to chilled collection tubes containing $12.5 \mu \mathrm{l}$ of ice-cold $2 \times$ binding buffer (EDTA Tris-HCL, $\mathrm{pH} 7.4, \mathrm{NaCl}$ $2 \mathrm{M}$, Tween $0.1 \%$ ). Four microliters of Myone C1 streptavidin magnetic beads (LifeScience Technology) was blocked with yeast tRNA and suspended in $25 \mu \mathrm{l} 1 \times$ binding buffer (EDTA Tris- $\mathrm{HCl}, \mathrm{pH} 7.4, \mathrm{NaCl} 1 \mathrm{~m}$, Tween $0.05 \%)$. Twenty-five microliters of chilled suspended beads were added into each sample and mixed well. Samples were incubated on ice for $10 \mathrm{~min}$ and then incubated at room temperature for up to $1 \mathrm{~h}$ with constant shaking. Beads were collected using a magnetic stand and washed with $1 \times$ binding buffer at room temperature twice for 2 min with constant shaking. Then samples were washed at $55^{\circ}$ with $1 \times$ binding buffer twice for $30 \mathrm{~s}$ each time, and with $1 \times$ TE buffer twice briefly. After washes, RNA was released from beads by adding $10 \mu$ l of $100 \mathrm{mM}$ DTT and incubation for 10 min. Five microliters of RNA was used for cDNA amplification using a SMART-Seq Ultra Low Input RNA Kit for Sequencing (Clontech). Amplified cDNA was fragmented with a Covaris ultrasonicator and RNAseq libraries were prepared using a TruSeq RNA Library Prep Kit (Illumina). High-throughput sequencing was performed on a Hiseq2000 platform, and six to eight samples were mixed in a single lane for each run. The sequencing quality of all the samples was checked by FastQC (http://www.bioinformatics.babraham.ac.uk/ projects/fastqc/). Tophat (Trapnell et al., 2010) was used to map the sequencing reads against mouse $\mathrm{mm} 10 \mathrm{ge}-$ nome assembly and annotation. The uniquely mapped reads were assigned to and counted in each individual gene by HTSeq-count (Anders et al., 2015) according to their coordinates. The data quality of the count data was examined by principal component analysis (PCA) and density distribution plotting. The genes of zero or very low expression level across all the samples were filtered out to minimize the interference of those genes in the following analysis and to increase the statistical detection power (Cambronne et al., 2012). The remaining genes were normalized by a geometry median approach, which was implemented in DESeq. We used ANOVA to determine which mRNAs were significantly enriched in a pairwise manner between lentiviral and retroviral samples (Cambronne et al, 2012). We also used DAVID (Database for Annotation, Visualization and integrated Discovery) in combination with Gene Ontology (GO) or Kyoto Encyclopedia of Genes and Genomes (KEGG) databases for functional analysis of significant enriched mRNAs. Violin and density plots were generated by ggplot2, an $\mathrm{R}$ package. The UCSC Genome Browser was used for sequencing data visualization. Other tools and scripts used for data parsing, analysis, and visualization were written in R, Linux shell, or Perl (available upon request). All of the raw data will be uploaded into the National Center for Biotechnology Information GEO (Gene Expression Omnibus) database. 
Table 1: Primer sequences

\begin{tabular}{|c|c|c|c|}
\hline Lrrc8b-F & CCA TCT GAC CTT CAT TCC CGA G & Lrrc8b-R & TCC CAG GAG TAG ACA CTG AAG C \\
\hline nova2-F & AAG CCT GAG GTG GTC AAC ATC C & nova2-R & GAC TGT TCC ATC ACC GCC TTC A \\
\hline dusp8-F & CTT ATC CAG CCT GCT ACA CGG A & dusp8-R & AGC TTG CTG AGC AGG ATG GAC A \\
\hline Kcnq3-F & AAG CCT ACG CTT TCT GGC AGA G & Kcnq3-R & ACA GCT CGG ATG GCA GCC TTT A \\
\hline Dpysl2-F & GAC CAT CTC TGC CAA GAC ACA C & Dpysl2-R & GGA ATG TAG CGT CCT GAG CCT T \\
\hline Mycbp2-F & СCT ACT GTG CAA ACT GGA CTC C & Mycbp2-R & CTT CGG CTT GAC TAG CTG AGT C \\
\hline Robo2-F & CCA CCA TCC AAA CCT CAG GTC A & Robo2-R & TCT GCC AGC TAT TGC TCA CCG A \\
\hline Slc27a4-F & GAC TTC TCC AGC CGT TTC CAC A & Slc27a4-R & CAA AGG ACA GGA TGC GGC TAT TG \\
\hline Ankhd1-F & CTG TTT CCA GGG TCG AGC AGA A & Ankhd1-R & СTT CCA ACC TCT GCA TAT CCT CC \\
\hline Ankrd17-F & GCA GCA AAT GGT GGA CAC CTA G & Ankrd17-R & CTA AGT AGC GCA CCA CCT TCA C \\
\hline Eif2c1-F & CTG CCT TCT ACA AAG CAC AGC C & Eif2c1-R & TCT GTC CAC AGT GGG TCA CTT C \\
\hline Eif2c3-F & CTT CTG TGT TCC AGC AAC CAG TG & Eif2c3-R & GGC ACA GTA TCT GCT TGG ATG G \\
\hline Cadm1-F & ACTTCTGCCAGCTCTACACGGA & Cadm1-R & CCCTTCAACTGCCGTGTCTTTC \\
\hline Chl1-F & GGAAAAGCCGTCATCACAGCGA & Chl1-R & GTGAGTCACACTGGCTTTCGCA \\
\hline Sorbs $1-\mathrm{F}$ & TATCAGCCTGGCAAGTCTTCCG & Sorbs1-R & CCCGTCTGATTCCCTCTTCACT \\
\hline Ncam1-F & GGTTCCGAGATGGTCAGTTGCT & Ncam1-R & CAAGGACTCCTGTCCAATACGG \\
\hline Elavl3-F & TGC AGA CAA AGC CAT CAA CAC CC & Elavl3-R & CCA CTG ACA TAC AGG TTG GCA TC \\
\hline Prox1-F & CTG AAG ACC TAC TTC TCG GAC G & Prox1-R & GAT GGC TTG ACG CGC ATA CTT C \\
\hline Elavl3-F & TGC AGA CAA AGC CAT CAA CAC CC & Elavl3-R & CCA CTG ACA TAC AGG TTG GCA TC \\
\hline $\mathrm{B} 2 \mathrm{~m}-\mathrm{F}$ & ACAGTTCCACCCGCCTCACATT & $\mathrm{B} 2 \mathrm{~m}-\mathrm{R}$ & TAGAAAGACCAGTCCTTGCTGAAG \\
\hline
\end{tabular}

\section{Laser capture microdissection}

Fresh-frozen coronal brain sections $(12 \mu \mathrm{m})$ were collected by cryostat sectioning on polyethylene napthalate membrane slides, and were fixed for $1 \mathrm{~min}$ in $75 \%$ ethanol, followed by staining for $1 \mathrm{~min}$ with Cresyl Violet acetate (1 $\mathrm{mg} / \mathrm{ml}$; Sigma-Aldrich) and a final wash in $100 \%$ ethanol for $1 \mathrm{~min}$. Cell populations from either the subgranular zone or the granular cell layer (GCL) of the dentate gyrus were laser captured using a Leica Microsystems laser microdissection system under an HC PL FL L 40×/0.60 XT objective (Leica Microsystems) and collected in lysis buffer (50 $\mu$ l; RLT buffer, Qiagen). Total RNA from laser capture microdissection (LCM) samples of the SGZ and GCL was isolated on an individual animal basis $(n=5)$ and extracted using an RNeasy Micro Kit (Qiagen). RNA was amplified linearly using SMART-Seq Ultra Low Input RNA Kit for Sequencing library prep kit (Clontech).

\section{Quantitative PCR of laser capture tissue samples}

RNA from laser-captured samples was extracted using the RNeasy Micro Kit. Genomic DNA was removed by on-column DNase I digestion. RNA amount and quality was monitored by an Agilent bioanalyzer. Five hundred picograms of RNA was used for cDNA amplification using the SMART-Seq Ultra Low Input RNA Kit (Clontech). Quantitative PCR was performed using amplified cDNA on an Opticon Real-Time PCR machine. iQ qPCR (BioRad) mastermix was used for all of the reactions. RNA expression levels were normalized to $\beta_{2}$-microglobulin mRNA levels. Primer specificity and genomic RNA contamination was monitored using the melting curve of the PCR products. Primer sequences were obtained from the
Origene validated quantitative PCR (qPCR) primer collection (Origene Technologies; Table 1). Statistical analysis was performed with Prism software (GraphPad Software). The two groups were compared using an unpaired nonparametric Mann-Whitney test, and significance was defined as $p<0.05$ (*).

\section{Results}

\section{In vivo pulse-chase detection of nascent mRNAs by TU tagging}

To investigate the differences in nascent mRNAs in adult-generated immature neurons 2 weeks postmitosis compared with mature granule cells, we refined the "TUtagging" technique for use in the CNS in vivo (Cleary et al., 2005; Zeiner et al., 2008; Miller et al., 2009). This approach provides high spatial and temporal resolution of changes in gene expression. TU tagging allows cell typespecific biosynthetic labeling of actively transcribed RNA within intact tissues, which is not possible with traditional transcriptome analysis that measures steady-state RNA levels (Miller et al., 2009; Gay et al., 2013). TU tagging exploits the activity of a Toxoplasma gondii uracil salvage enzyme, UPRT, which is not present in mammalian cells, but exogenous expression can be targeted to specific cell types within intact tissue (Fig. 1A, left). Under normal conditions, UPRT converts uracil to uridine monophosphate. However, following pulse labeling with the modified analog 4-TU, thiol groups are incorporated into nascent RNA in UPRT-expressing cells within a narrow time window (Fig. 1A, middle and right; Cleary et al., 2005; Zeiner et al., 2008). Thiol labeling of nucleotides by UPRT 
A

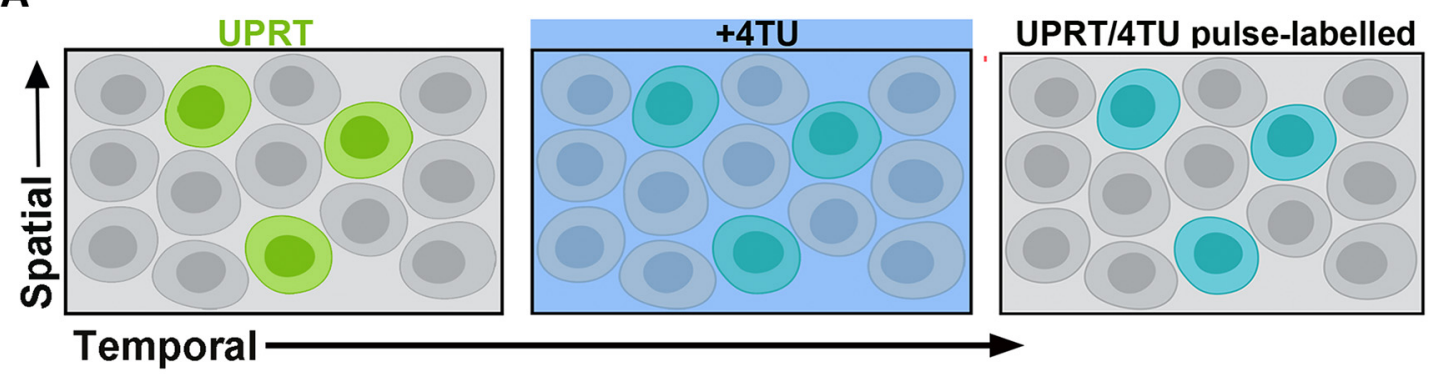

B

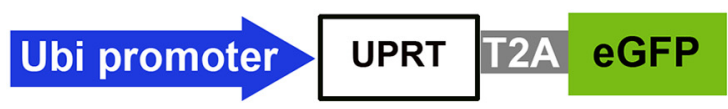

C

Uracil Incorporation in HEK-293T cells

Uracil Incorporation in Cortical Neurons
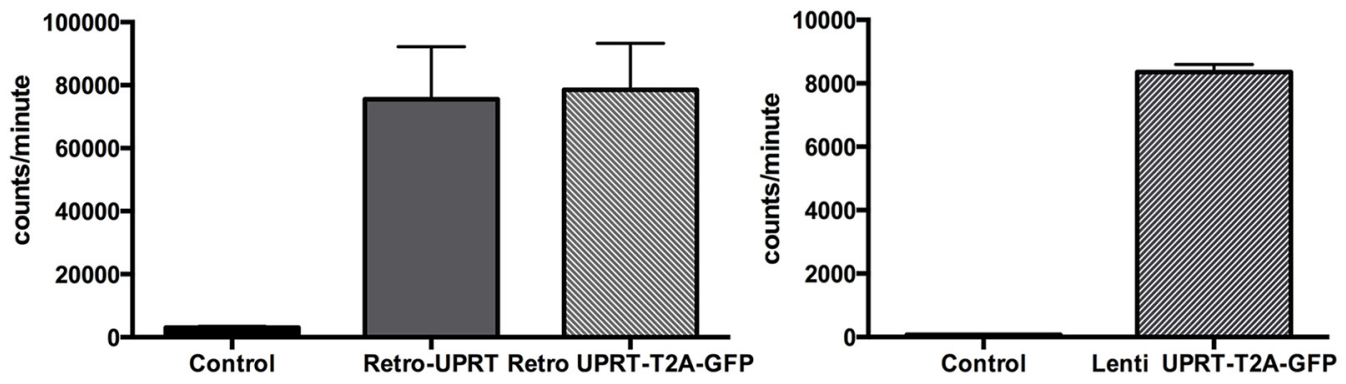

D

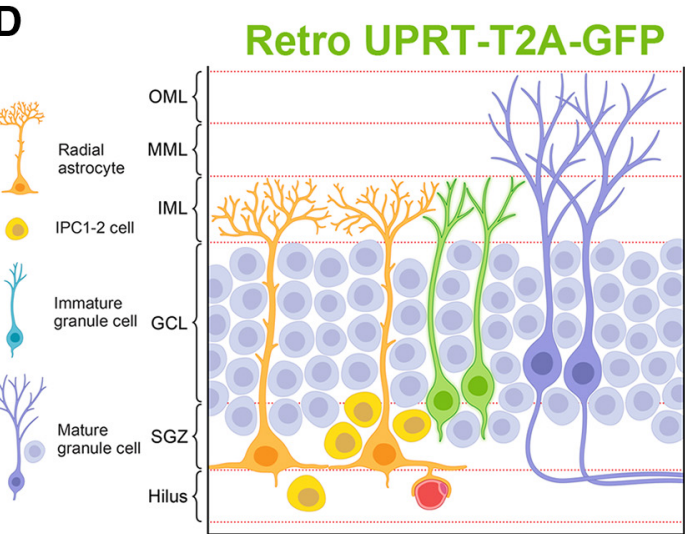

\section{Lenti UPRT-T2A-GFP}
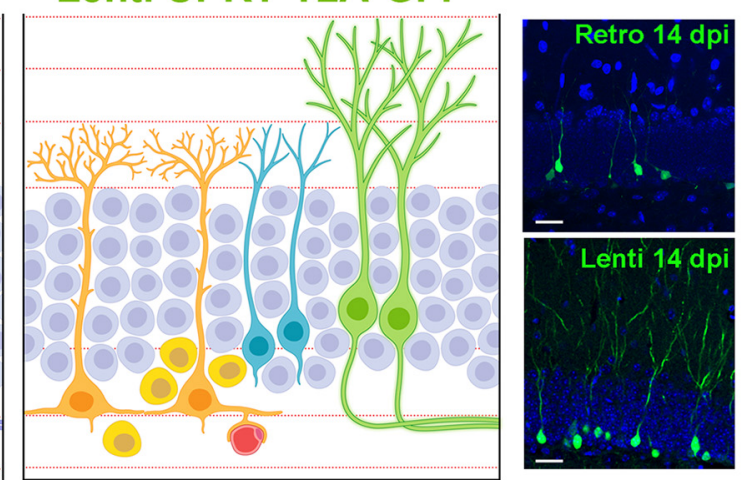

Figure 1. TU tagging in the adult DG. $\boldsymbol{A}$, Overview of TU-tagging method: UPRT cell type specificity confers spatial control (green), and pulse chase of 4-TU provides temporal control (blue). B, Construct for virus-mediated UPRT expression. C, Uracil was incorporated in HEK-293 T cells transduced with UPRT-expressing retroviruses (left) and in neonatal hippocampal neurons transduced UPRT-expressing lentivirus (right). Data are plotted as the mean \pm SD. $\boldsymbol{D}$, Schematic of strategy for TU tagging of immature newborn and mature neurons with UPRT-expressing retroviruses and lentiviruses, respectively, in the adult DG (left and middle). Representative images of newborn and mature neurons that robustly express UPRT-T2A-GFP retrovirus (right top) and lentivirus (right bottom) at $14 \mathrm{DPI}$. Scale bar, $20 \mu \mathrm{m}$.

has little or no effect on cellular physiology (Cleary et al., 2005), and TU-tagged RNAs then can be biotinylated, purified, and further processed for RNAseq.

To achieve cell type specificity of labeling in the adult dentate gyrus in vivo, we used viral constructs to target UPRT gene expression to granule cells. Virus-mediated cell manipulations are efficient tools for investigating molecular mechanisms involved in adult DG neurogenesis in an intact brain environment. For example, stereotaxic injections into the dentate gyrus of retroviral vectors, which are selective for dividing cells, have been used for birth dating and labeling adult newborn neurons (van Praag et al., 2002), whereas VSV-g pseudotyped lentiviral vectors show a tropism toward mature granule cells (Lois et al., 2002; Luikart et al., 2011a, 2011b). Thus, we designed matching retroviral and lentiviral vectors expressing a bicistronic reporter construct containing the coding sequence for $T$. gondii UPRT and green fluorescent pro- 
tein (GFP) separated by a T2A peptide linker sequence under the control of the ubiquitin promoter (Fig. 1B), to allow high-level expression in vivo.

To determine the efficiency of the UPRT viral vectors, we tested ${ }^{3} \mathrm{H}$-uracil incorporation into RNA of HEK-293 T cells. Control cells lacking the UPRT transgene showed minimal ${ }^{3} \mathrm{H}$-uracil incorporation, whereas cells transduced with a retrovirus expressing UPRT or UPRT-T2A-GFP showed robust incorporation (Fig. 1C, left; control, 3,031 \pm 435; retro-UPRT, 75,527 \pm 16,645; retro-UPRT-T2AGFP, $78,518 \pm 14,473 ; n=3)$. Additionally, primary cultures of neonatal hippocampal neurons infected with a lentivirus expressing UPRT-T2A-GFP demonstrated both UPRT activity (Fig. 1C, right; control, $72 \pm 1$; lenti-UPRTT2A-GFP, 8,352 $\pm 245 ; n=3$ ), as assayed by ${ }^{3} \mathrm{H}$-uracil incorporation, and GFP expression as assayed by immunofluorescence (data not shown), indicating that viral expression of UPRT led to cell-specific uracil incorporation.

\section{Retroviral and lentiviral expression of UPRT-T2A- GFP}

To confirm the cellular specificity of UPRT-T2A-GFP virus-mediated transfer in vivo, we first analyzed the pattern of GFP expression in mice 2 weeks after stereotaxic injection of retroviral and lentiviral vectors into the dentate gyrus of young adult mice. The expected and observed labeling patterns of GFP-labeled neurons with retroviral or lentiviral constructs are shown in Figure 1D. Retrovirally infected $\mathrm{GFP}^{+}$cells at $14 \mathrm{~d}$ postinjection (DPI) exhibited typical morphology of adult-generated immature newborn granule cells with cell bodies located in the SGZ and short dendrites terminating in the inner molecular layer (Fig. 1D, right top). In lentivirus-injected animals at 14 DPI, GFP ${ }^{+}$ cells had mature neuronal morphologies (Fig. 1D, right bottom). The cell bodies of lentivirally labeled cells spanned the GCL with highly arborized dendritic processes extending fully across the molecular layer consistent with mature granule cells. We characterized the phenotypes of the two GFP $^{+}$populations (Fig. $2 A, B$ ) using double immunolabeling with selective markers for progenitors (nestin, GFAP), immature neurons (DCX), mature neurons (Calbindin, NeuN), and glia (GFAP, CD68, Olig2; Fig. $2 C-H$ ). As summarized in Figure 2, I and $J$, the vast majority of the retrovirally labeled cells $(95.3 \pm 1.9 \%)$ were immature neurons $\left(\mathrm{DCX}^{+}\right)$, whereas only a few cells $(2.3 \pm$ $1.2 \%$ ) were neural progenitors (nestin ${ }^{+}$) or oligodendrocytes $\left(2.2 \pm 0.8 \%\right.$; Olig2 $\left.{ }^{+}\right)$. None of the GFP ${ }^{+}$cells were astrocytes or microglia, as assessed by immunostaining with GFAP and CD68, respectively. In contrast, lentivirally transduced $\mathrm{GFP}^{+}$cells labeled with the mature neuronal marker Calbindin (85 $\pm 3.5 \%)$, although a small proportion did express DCX (15.6 $\pm 4.3 \%)$. No colocalization was detected with astrocytic $\left(\mathrm{GFAP}^{+}\right)$or microglia markers $\left(\mathrm{CD} 8^{+}\right)$, and only $1.8 \pm 0.9 \%$ labeled with the oligodendrocyte marker Olig2 ${ }^{+}$. Immunostaining with an antibody against Mac-2, a marker of activated microglia, 2 weeks following both retroviral and lentiviral injections revealed weak labeling only along the needle path, suggesting that there was negligible injury/inflammation caused by the viral vectors or the injection (data not shown). These results indicate that retroviral and lentiviral UPRT-T2A-GFP vectors labeled relatively pure populations of DG immature newborn and mature granule cells in the adult brain in vivo.

\section{Generation of RNAseq libraries}

To purify thiol-labeled RNA from UPRT-expressing immature and mature neurons, WT mice were injected with either our retroviral or lentiviral vectors $14 \mathrm{~d}$ prior to injection of $4-\mathrm{TU}(1.25 \mu \mathrm{l} / 1 \mathrm{~mm})$ in the dorsal third ventricle. Sixteen hours later, total and TU-tagged RNA were purified from microdissected dentate gyri. Dentate gyri from 4-TU-treated mice that had not been injected with UPRT viral constructs served as a biotinylation control. RNAseq libraries were generated from three hippocampi (each sample included UPRT plus 4-TU, 4-TU alone, and total RNA input) and subsequently were analyzed in biological triplicates (lentiviral dataset 1 and retroviral dataset 2) or quadruplicates (retroviral dataset 1). Libraries were sequenced to a depth ranging from 25 to 39 million reads. After alignment with mouse genome assembly $\mathrm{mm} 10$ with RefSeq gene annotation, each sample had a mapping rate of $\sim 80 \%$ to the reference genome and annotation. The uniquely mapped reads were then assigned to the corresponding transcripts.

The count data examined by violin and density plots showed similar shapes (Fig. 3A, left and middle), indicating the consistency of RNAseq libraries across the datasets. Datasets were clustered into three separate groups through PCA (Fig. 3A, right). After filtering out very lowly expressed genes and normalization, the data shapes of all datasets were consistent with a Gaussian distribution, whereas the PCA plots retained their corresponding clustering characteristics, indicating that clusters of retrovirus-labeled samples are distinct from lentiviruslabeled samples, suggesting differential expression patterns (Fig. 3B). To examine whether there was differential expression of nascent mRNAs between adult born immature neurons 2 weeks postmitosis and mature granule cells, we compared each retroviral dataset to the lentiviral dataset. The dispersion or variance of the count data was estimated and agreed with the regression line, indicating a good fit of our filtered datasets to the binomial statistical model used in DEseq (Fig. 3C). The DEseq analysis revealed genes that were significantly enriched in the retroviral (red) and lentiviral (blue) samples. Differential expression was determined using ANOVA for each pairwise comparison, with the cutoff of false discovery rate (FDR) at $\leq 5 \%$ (Fig. 3D).

\section{Differential gene expression analysis in immature and mature granule cells}

Our experimental strategy using TU tagging allowed us to compare gene expression profiles in immature neurons ( $\sim 14 \mathrm{~d}$ postmitosis) that have yet to fully elaborate dendrites or receive excitatory synapses with the relatively mature state of neurons at 4 weeks postmitosis. We did not compare the datasets to input (whole dentate RNA) because of the inherent cellular heterogeneity in RNA from the whole dentate. The differential expression of nascent mRNAs was visualized using a heat map (Fig. 

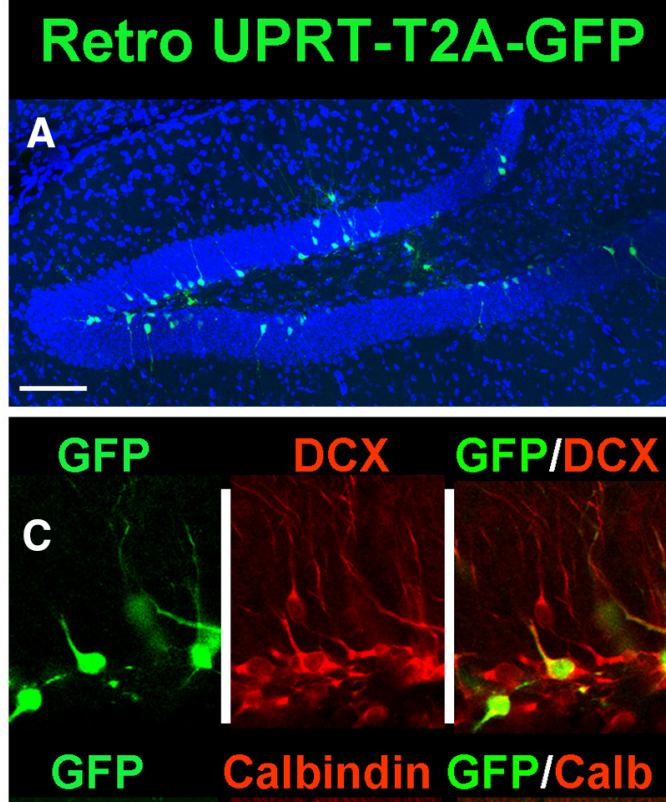

E
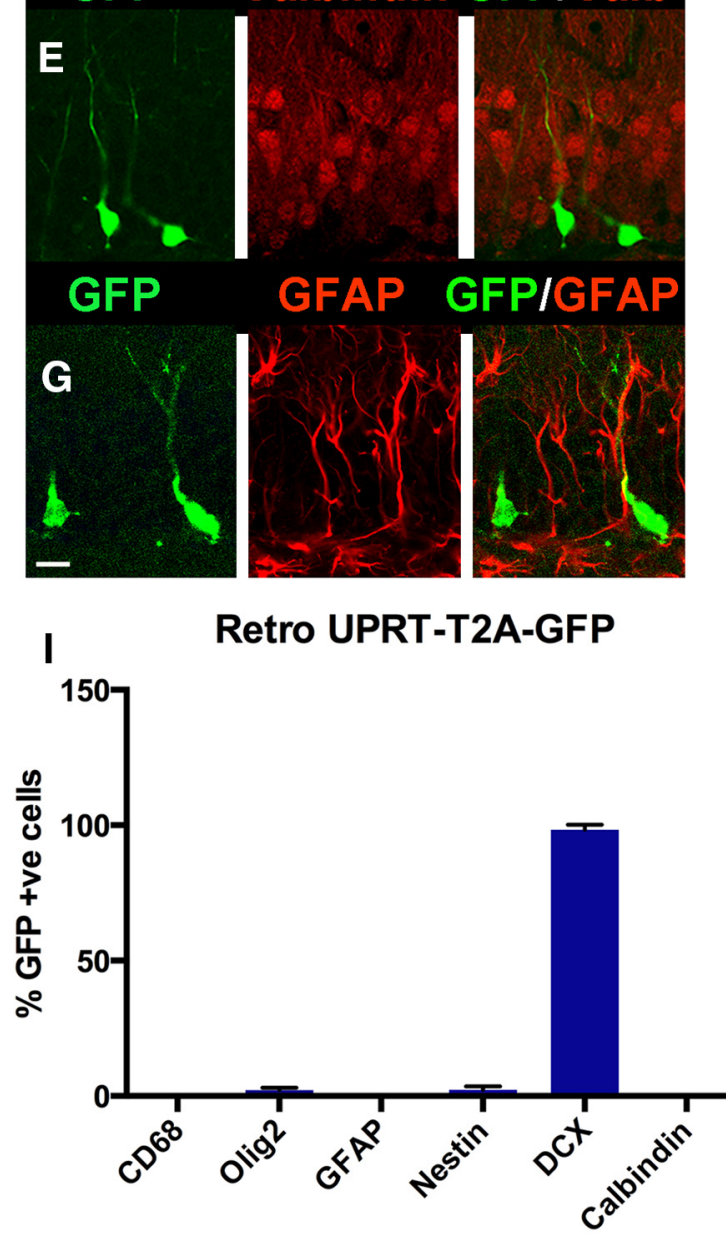
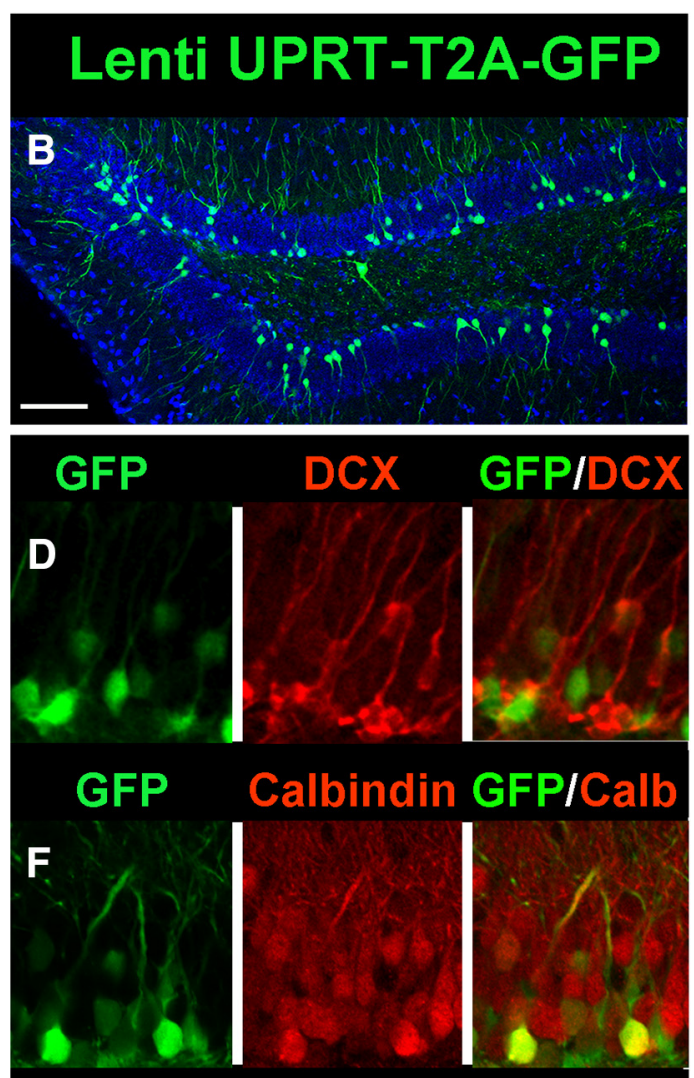

GFP
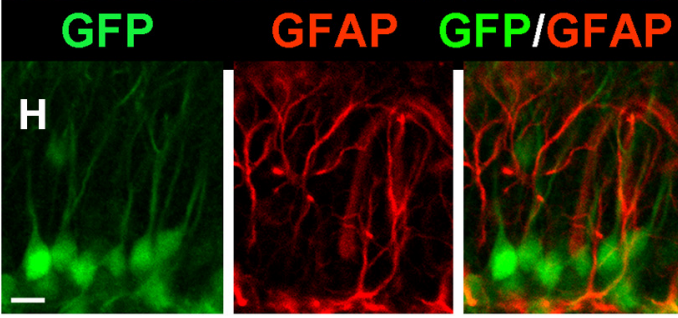

$J$

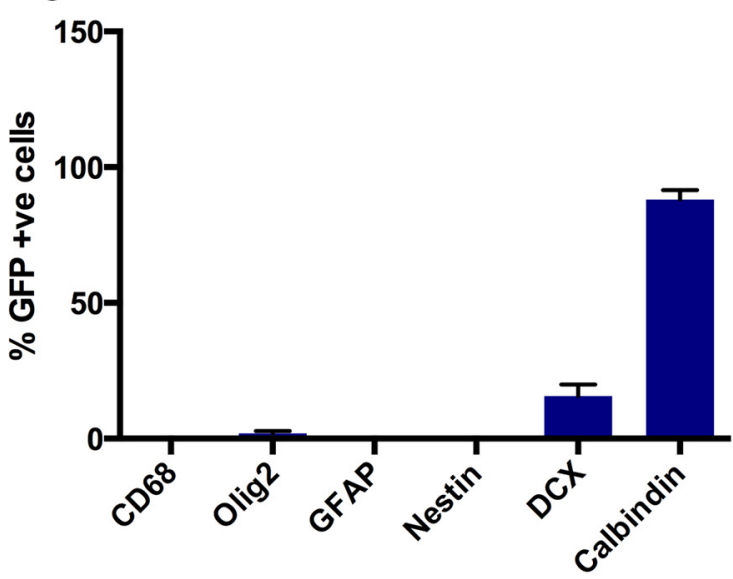

Figure 2. Validation of cell specificity of UPRT-expressing retroviral and lentiviral constructs by immunocytochemistry at 14 DPI. $\boldsymbol{A}$, $\boldsymbol{B}$, GFP staining in hippocampal sections from mice injected with UPRT-T2A-GFP retrovirus $(\boldsymbol{A})$ and lentivirus $(\boldsymbol{B}) 14$ DPI. Scale bar, $50 \mu \mathrm{m}$. $\boldsymbol{C}-\boldsymbol{H}$, Immunostaining for retrovirally and lentivirally labeled cells with the immature neuron marker DCX $(\boldsymbol{C}, \boldsymbol{D})$, mature neuronal marker calbindin $(\boldsymbol{E}, \boldsymbol{F})$, and the astrocytic marker GFAP $(\boldsymbol{G}, \boldsymbol{H})$. $\boldsymbol{I}, \boldsymbol{J}$, Retrovirus-expressing neurons were labeled with DCX, but not mature neuron or glial markers at $14 \mathrm{DPI}(\boldsymbol{I})$, whereas lentivirus-expressing neurons were labeled with the mature cell marker calbindin as well as a small population of DCX $(\boldsymbol{J})$. Scale bar, $10 \mu \mathrm{m}$. Data are plotted as the mean \pm SD. 
A $\quad \log _{2}$ raw counts

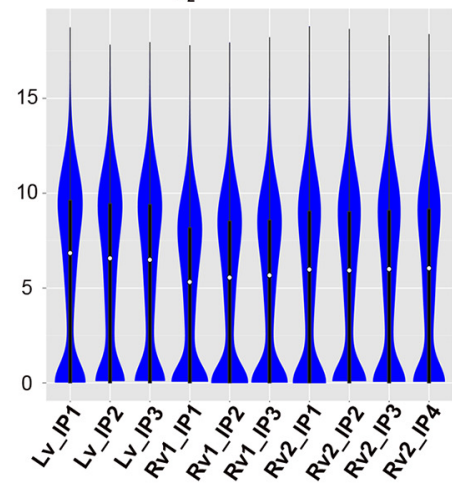

B

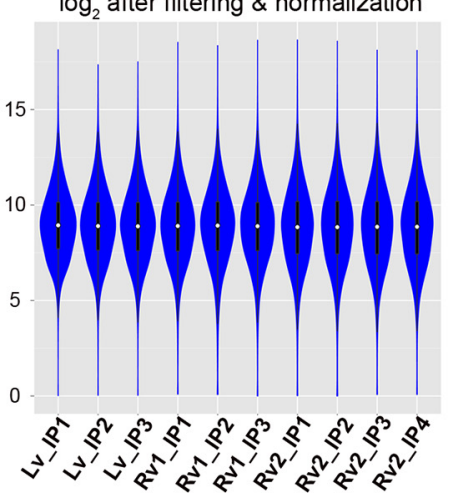

Data Quality Control

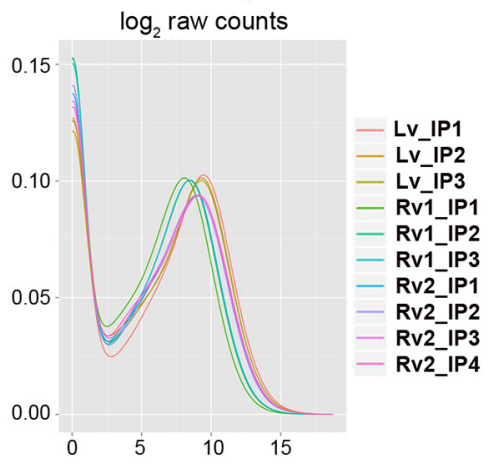

Filtering \& Normalisation

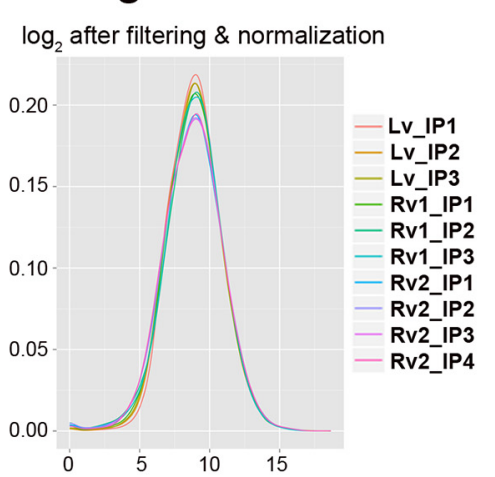

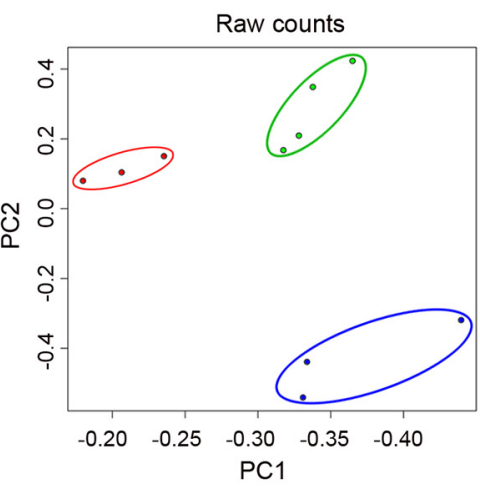

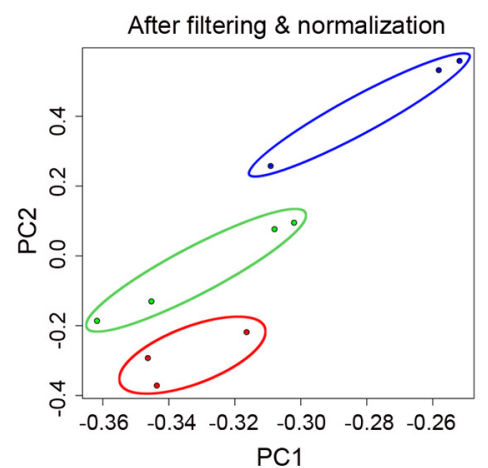

\section{Dispersion Estimation}

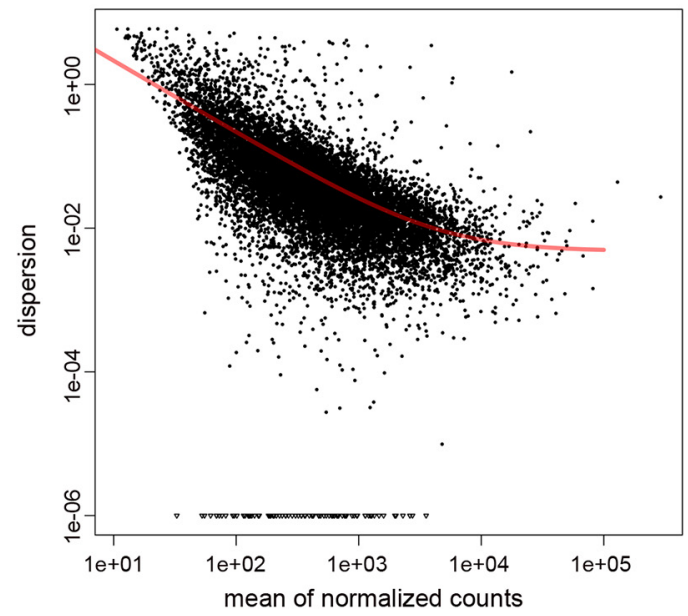

D Differential Analysis

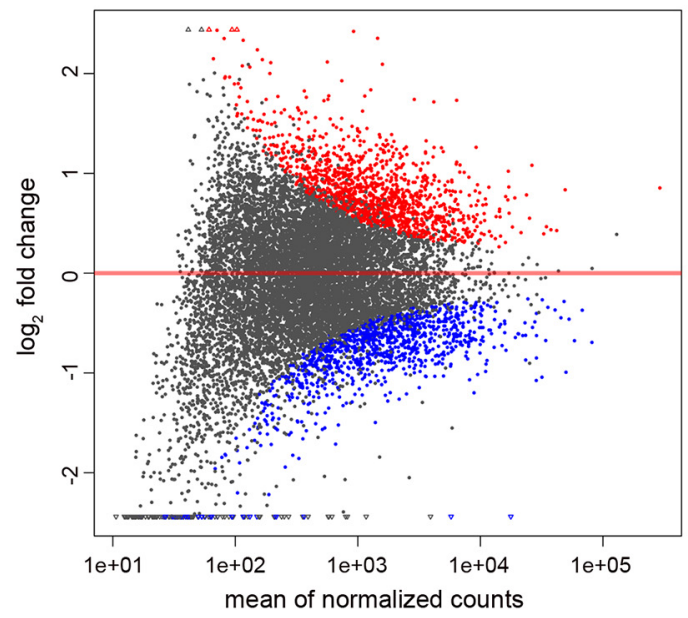

Figure 3. Flowchart for data analysis and quality control of RNAseq. $\boldsymbol{A}$, The counts assigned to all the genes after mapping were visually checked by violin plot (left; $y$-axis, log reads per gene) and density (middle; $x$-axis, log reads per gene; $y$-axis, number of genes), and by PCA (right). In the PCA plot, the samples clustered into the following three groups: lentiviral dataset is in blue; retroviral dataset 1 is in green; and retroviral dataset 2 is in red. $\boldsymbol{B}$, The data on counts were subsequently filtered to remove the lowly expressed genes, normalized, and also checked with data shapes and PCA analysis. The color scheme of the three groups in the PCA plot is the same as in $\boldsymbol{A}$. C. The dispersion of the filtered and normalized data were estimated and compared with the regression line (red). $\boldsymbol{D}$, The data were tested with a negative binomial model, and ANOVA was used to determine significantly enriched genes and is shown in the $\mathrm{M}$ (log ratios) and $\mathrm{A}$ (mean average) plot. The red dots depict the significantly enriched genes in the retroviral dataset, and the blue dots depict the depleted genes (i.e., genes enriched in the lentiviral dataset).

$4 A$ ), in which red indicates upregulation and green indicates downregulation. The heat map shows the replicates from the lentiviral dataset with retroviral dataset 1 and dataset 2 . There were 457 genes identified as specifically 
A

B
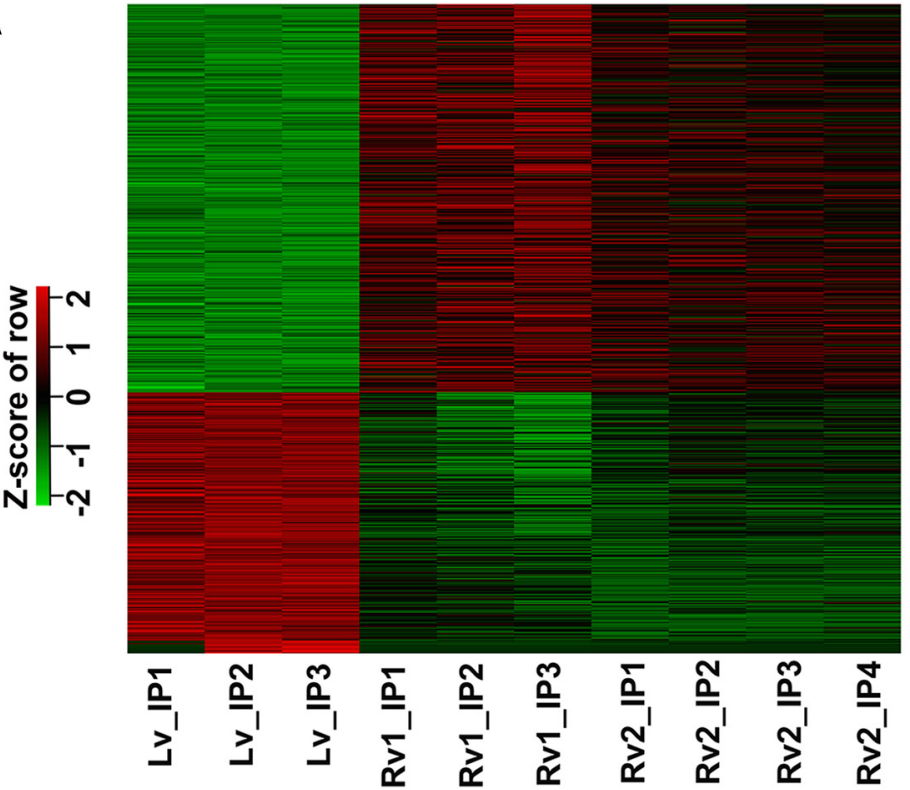

Retrovirus GO clusters

Synapse and plasma membraneAxon and neuron projection-

Synaptic transmission and neurological system process-

Synaptosome and membrane fractionSynaptic vesicle and cytoplasmic vesicleHistone modificationlon bindingNeuron differentiation and developmentTranscription and regulationCytoskeleton organizationGTPase activityNeurotransmitter transportIon channel activityCell motion and migrationGene expression regulationTranscription factor and cofactor activityPhospholipid processEnzyme bindingRegulation of synaptic plasticityGene silencing-

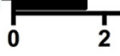

Enrichment Factor

C

Lentivirus GO Clusters

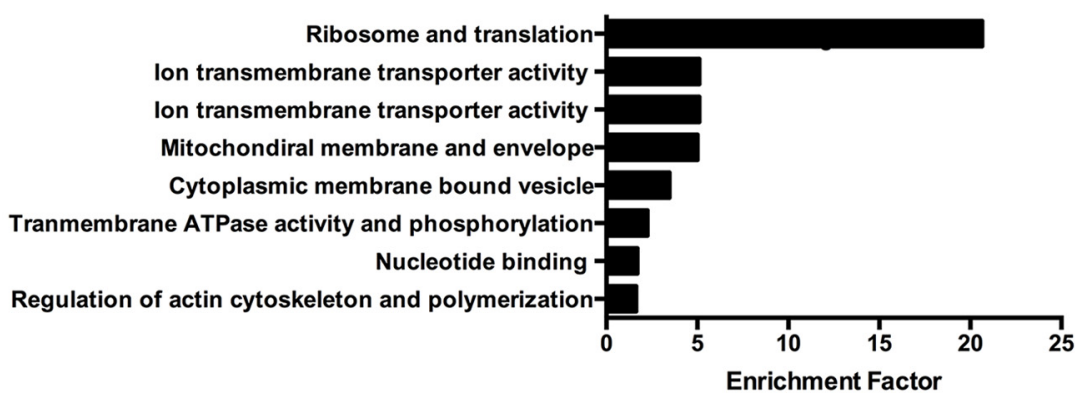

Figure 4. Differential expression of mRNA between immature and mature DG granule cells. $\boldsymbol{A}$, The retroviral datasets 1 and 2 were separately compared with the lentiviral dataset using a heat map. Each comparison generated a list of significantly changed genes. Both lists were merged into a new single list by requiring that the genes appeared in both lists. The heat map was plotted based on this new list. The 457 genes in the top half of the heat map were specifically enriched in the retroviral datasets. The 305 genes in the bottom half of the heat map were specifically enriched in the lentiviral dataset. $\boldsymbol{B}, \boldsymbol{C}$, The top enriched ontological clusters of DAVID categories are reported for the retroviral $(\boldsymbol{B})$ and lentiviral $(\boldsymbol{C})$ datasets. 
enriched in the retroviral datasets (Fig. 4A, top; Table 2, left) and 305 genes specifically enriched in the lentiviral dataset (Fig. 4A, bottom; Table 2, right). There was a high degree of consistency between the two retroviral datasets with fold increases (FDR criteria $<0.05$ ) that ranged from 1.15 to 7.34 . In this comparative analysis, many significantly enriched genes showed only small fold changes (FCs). In the case of the 457 genes in the retroviral dataset, there were 42 in dataset 1 with a fold change of $>2$, and 106 genes in dataset 2 with a fold change of $>2$. Because the pulse-labeling strategy with TU-tagging biases our analysis toward nascent RNAs, large fold changes in long-lived RNAs would be masked. This point emphasizes that TU tagging provides different information than transcriptome approaches based on steady-state RNA levels such as qPCR or microarrays.

To examine common functional relationships among the top differentially expressed genes, we performed GO analysis across the molecular function, cellular component, and biological process domains. The top GO clusters for genes differentially upregulated in the retroviral datasets and lentiviral dataset are presented in order of DAVID enrichment score (Fig. 4B,C). The top GO categories in the retroviral datasets (Fig. 4B) were linked with synaptic function (e.g., synapse and plasma membrane, synaptic transmission, synaptic vesicles), neuronal morphology (e.g., cell morphogenesis during neuronal differentiation, axon guidance, and cell motion), and transcriptional regulation (e.g., chromatin organization, histone methylation, and DNA modification). These general patterns are consistent with the early phases of dendritic and synaptic development of newborn neurons at 2 weeks postmitosis (see also Miller et al., 2013). Transcription factors were the single largest category with $>65$ genes among the 457, only some of which have previously been linked to early neuronal development (Table 2).

At the single-gene level, the differential transcription profile of 2-week-old adult born neurons revealed by our TU-tagging analysis showed a high overlap with transcripts previously linked to adult hippocampal neurogenesis and maturation. For example, transcripts for developmentally regulated proteins used as markers for immature granule cells were significantly upregulated in the following retroviral datasets: Prox1 (FC, 2.17; $q=$ 5.9E-12); Tbr1 (FC, 1.97; $q=0.06$ ); and Ncam (FC, 1.71; $q=2 \mathrm{E}-20)$. Several genes associated with the maturation of immature dentate granule cells were also upregulated, including CREB binding protein (CBP; FC, 2.04; $q=$ 2.6E-11), which regulates newborn granule cell development and survival as triggered by GABA-mediated depolarization (Nakagawa et al., 2002; Jagasia et al., 2009). Likewise, KIf9 (FC, 1.59; $q=6.4 \mathrm{E}-8$ ) acts in terminal stages of neuronal differentiation (Scobie et al., 2009), and Girdin (FC, 1.23; $q=0.02$ ) regulates axonal development and migration of immature dentate granule cells (Enomoto et al., 2009). These results indicated that these tagged nascent mRNAs are dynamically upregulated in immature newborn granule cells.

At the synaptic level, the retroviral datasets had enrichment of the NMDA receptor subunit gene Grin $2 b$, which is expected to be expressed at a higher level in immature (FC, 2.31; $q=1 \mathrm{E}-18)$ ], but Grin2a (FC, 1.66; $q=0.0019)$, which shows activity-dependent expression, was also enriched, perhaps indicating that the TU-tagging approach captured the increase in nascent transcripts just as synaptogenesis begins. To link the enriched genes to signaling pathways, we analyzed the enriched genes in the retroviral datasets using the KEGG pathways, which revealed an annotation cluster containing the highest enrichment in the following three terms: axon guidance, Wnt signaling pathway, and long-term potentiation (LTP; see Discussion).

Between 2 and 4 weeks postnatally, dentate granule cells show a dramatic expansion of their dendritic arbors and the formation of excitatory synaptic innervation from the perforant path. Thus, we expected to see differential expression of synaptic genes in the lentiviral dataset, representing mature granule cells, compared with the retroviral datasets, representing immature granule cells. This was not the case. In contrast, the lentiviral dataset showed differential expression in genes associated with metabolic regulation (ribosomes, mitochondria, and oxidative phosphorylation), ion transporters necessary to maintain ion gradient action potential and synaptic activity, and actin polymerization/remodeling, a biochemical process associated with stabilization of the dendritic spines and morphological changes at synapses (Fig. $4 C$ ). It should be emphasized that synaptic genes are of course expressed in mature cells, but our results are comparative in order to reveal differences in patterns between immature and mature granule cells. Thus, with maturation the enriched genes in mature granule cells reflect the high cellular metabolic demand imposed by the expansion of the dendritic membrane, synapse formation, and increased synaptic activity.

\section{Comparison of nascent transcript levels obtained by TU tagging with steady-state RNA levels}

Two important caveats must be considered in comparing our TU tagging results with traditional transcriptomics. First, TU tagging detects nascent transcripts, which may be distinct from the steady-state mRNA levels obtained by PCR or microarrays. Second, our analysis compared two relatively similar neurons because we were interested in the pattern shifts in gene expression during this period. To compare the RNAseq results with a steady-state RNA method, we combined LCM with qRT-PCR to examine steady-state mRNA levels of selected genes between the subgranular zone, where the majority of the immature newborn cells reside, and the outer margin of the granule cell body layer, which is composed almost entirely of mature granule cells. RNA was isolated from two cell-diameter-wide segments at the inner or outer border of the GCL (representing the SGZ and GCL, respectively; Fig. 5A) and amplified for qRT-PCR. mRNA expression levels of 26 genes selected at random from the top GO clusters enriched in the retroviral datasets were analyzed in both SGZ and GCL. Sixteen of the 26 genes (62\%) upregulated in the retroviral data were also upregulated $(p<0.05)$ in the 
Table 2: Genes specifically enriched in retroviral and lentiviral datasets

\begin{tabular}{|c|c|c|c|c|c|c|c|c|c|c|c|}
\hline \multicolumn{7}{|c|}{457 genes enriched in retroviral datasets } & \multicolumn{5}{|c|}{307 genes enriched in lentiviral datasets } \\
\hline Gan & Psd & Phc3 & Actb & Scn3a & Rap1gap2 & Tef & Arf1 & Rps23 & Csdc2 & Uqcrc1 & Gpx1 \\
\hline Speer4b & Purb & $\begin{array}{l}\text { C230081A13 } \\
\text { Rik }\end{array}$ & Swi5 & Osbp/6 & $D m \times 12$ & Npepps & Ube2d3 & Gdi2 & $\begin{array}{l}2900064 A 13 \\
\text { Rik }\end{array}$ & Tspyl3 & Fhl2 \\
\hline Nova2 & $\begin{array}{l}\text { A930013F10 } \\
\text { Rik }\end{array}$ & Appbp2 & Ocrl & Efr3b & Dlg3 & Med13 & Gnb2/1 & Dars & Rps20 & Aup1 & Ap2s1 \\
\hline Dynll2 & $\begin{array}{l}\text { Tnrc6b+ } \\
\quad \text { Mir5113 }\end{array}$ & Nipbl & Nucks1 & Taok1 & Ankrd17 & Pde8b & Rp/21 & Cox4i1 & Guk1 & Rps12 & Ppp5c \\
\hline LOC626693 & Gm6300 & Dlg2 & $E p b 4.111$ & Raph1 & $\begin{array}{l}1810041 L 15 \\
\text { Rik }\end{array}$ & Mtap1b & Rp/23 & Cdk5 & Hpcal1 & $\begin{array}{l}2410006 H 16 \\
\text { Rik }\end{array}$ & Gpr37/1 \\
\hline Lrrc8b & Nav2 & Ash1l & $\begin{array}{l}6820431 F 20 \\
\text { Rik }\end{array}$ & Jph1 & Unc80 & Trim33 & Atp5a1 & Yipf5 & Atp5b & Flot1 & Coro1a \\
\hline Tbrg3 & Neurl1b & Ylpm1 & Rnf182 & $\begin{array}{l}\text { 6430704M03 } \\
\quad \text { Rik }\end{array}$ & Lrrc4 & Nsd1 & Rp/37a & Tmem109 & $R p / 18$ & Ifi27/1 & Ninj1 \\
\hline Phxr4 & Atxn1 & Pwwp2a & Ncam1 & Wipf3 & Kif1b & Ahcyl2 & $D b i$ & Prnp & Tmem59l & Gpc5 & Gsn \\
\hline Cmah & Ncoa6 & MII2 & Arhgef12 & Slc4a7 & Dnmt3a & Gabrb3 & Rp/29 & Tubb3 & Spag7 & Dnalc4 & Elovi7 \\
\hline Ppm1I & Mbtd1 & Csmd1 & Ptpre & Camta1 & Ptp4a2 & Mgea5 & Pnkd & $\operatorname{Sec} 22 b$ & $P d c d 6$ & Bex1 & Sf3b4 \\
\hline $\begin{array}{l}\text { 5031426D15 } \\
\text { Rik }\end{array}$ & Cdr1 & Plxna2 & Ldoc1I & Brd3 & Glg1 & Atf6 & Vdac2 & Psma5 & $\operatorname{Actg} 1$ & Atp5d & Pnpla2 \\
\hline Kcnq3 & C77370 & Tanc2 & Itsn1 & Zdhhc17 & Gabrb2 & Sphkap & Reep5 & Gucy1b3 & Ube2a & $\begin{array}{l}2610301 G 19 \\
\text { Rik }\end{array}$ & Suclg2 \\
\hline Grin2b & Olfr613 & Ranbp10 & $A p c$ & Cnksr2 & Fyco1 & Slc1a2 & Ndufs3 & Cox8a & Tmco1 & Mrp/49 & Rbck1 \\
\hline $\begin{array}{l}\text { 1700080N15 } \\
\text { Rik }\end{array}$ & Ryr2 & Arhgef9 & Usp54 & Chl1 & Adcyap1r1 & Rac1 & Morf4l2 & Actr1b & $T b c b$ & $H k 1$ & Spp1 \\
\hline Nav3 & MII1 & Ralgapa2 & Kif21a & Ablim1 & Adcy 1 & Ank2 & Sparc & Tssc1 & Rps3a & Coq6 & Gadd45g \\
\hline Gatad2b & Kbtbd11 & Larp $4 b$ & Kif1a & Hnrnpd & Ip6k1 & Tnik & Hрса & Sec11c & Ptgds & Tmem85 & Gltscr2 \\
\hline Bmpr2 & Ssbp3 & Eif2c1 & Fzd3 & Hivep2 & Golgb1 & Ppp1r9a & Rps6 & Papss1 & $\begin{array}{l}\text { Psmb5+ } \\
\quad \text { Mir686 }\end{array}$ & Rplp1 & Med18 \\
\hline Grin2a & Fam178a & Atm & Srgap3 & Hipk1 & Ank & Dync1h1 & $\begin{array}{l}\text { Rpl13a+ } \\
\text { Snord33+ } \\
\text { Mir5121 }\end{array}$ & Dstn & Rp/7a & Mrp/12 & $R b p 1$ \\
\hline Arhgap32 & Tet1 & Dpp8 & Srek1 & Herc2 & Ube3b & Ubr5 & Ndufa10 & Ywhaq & P4htm & Mcrs1 & Rps10 \\
\hline $\begin{array}{l}\text { 4930470H14 } \\
\text { Rik }\end{array}$ & Ergic1 & Setx & Ncor1 & $C b / b$ & $R a b 6 b$ & Kpnb1 & Gad1 & Rp/27 & Maea & $\begin{array}{l}1810063 B 05 \\
\text { Rik }\end{array}$ & Dohh \\
\hline Nup50 & Vps13c & Rmnd5a & KIf9 & Ankhd1 & Pum1 & Camk2n1 & Rps24 & $\begin{array}{l}0610007 C 21 \\
\text { Rik }\end{array}$ & Arl1 & Snrpb & Mib2 \\
\hline Onecut2 & Sobp & Malat1 & Huwe1 & Мyо9а & Ccdc88a & $\begin{array}{l}2610507 B 11 \\
\text { Rik }\end{array}$ & Atp6v1g2 & Uba2 & Psmd8 & Gm12657 & Tuft1 \\
\hline Cdc73 & Adcy 9 & Fam40a & Opcml & Sbf2 & Ankrd12 & $D s p$ & Rps17 & Eef1a1 & Psmd6 & Sec61b & Sulf1 \\
\hline Hrk & Srrm2 & Atxn2 & Lyst & $\begin{array}{r}\text { Mir770+ } \\
\text { Meg3 }\end{array}$ & Tmem132b & Phactr1 & Rplp2 & Timm23 & $\begin{array}{l}1110002 B 05 \\
\quad \text { Rik+ } \\
\text { Mir1892 }\end{array}$ & Gpx4 & Enpp2 \\
\hline Gm3893 & $\begin{array}{l}\text { A230073K19 } \\
\text { Rik }\end{array}$ & Plxna4 & Gnaq & Aldh5a1 & Snx27 & Ppig & $R p / 36$ & Rnf7 & Txn/1 & $B s g$ & $\begin{array}{l}1500015010 \\
\text { Rik }\end{array}$ \\
\hline$T b / 1 x$ & Clmn & Nfat5 & $\begin{array}{l}2900026 A 02 \\
\text { Rik }\end{array}$ & Syngr1 & Scaf11 & Syn2 & Rp/35a & Pttg1ip & Slbp & Scrn1 & Kcnj13 \\
\hline Pex5l & Tjp1 & Luzp1 & Gucy1a2 & Scn2a1 & Hecw1 & B4galt6 & Rp/24 & Dynll1 & Rps27a & Puf60 & Cldn1 \\
\hline Mib1 & Ptprd & $\begin{array}{c}1810026 B 05 \\
\text { Rik+ } \\
\text { Chd2 }\end{array}$ & Rph3a & Herc1 & Gfod1 & Zfr & Rp/14 & Aarsd1 & Prelid1 & Mlc1 & Col8a1 \\
\hline Palm2 & $\begin{array}{l}\text { Atp6v0a4+ } \\
\text { D630045J12 } \\
\text { Rik }\end{array}$ & $\begin{array}{l}\text { 6230409E13 } \\
\text { Rik }\end{array}$ & Fat3 & Arhgap20 & $\begin{array}{l}\text { D430041D05 } \\
\text { Rik }\end{array}$ & Gria1 & Pgam1 & Rps11 & Fabp5 & Txndc15 & Slc4a5 \\
\hline Kdm2a & Mnt & Tacc2 & $\begin{array}{l}9930021 J 03 \\
\text { Rik }\end{array}$ & Smad3 & Sorbs 1 & Kidins220 & Npm1 & Manf & $\begin{array}{c}\text { Gm12191+ } \\
\text { Rp/30 }\end{array}$ & Chchd2 & Clic6 \\
\hline D10Bwg1379e & Eif2c3 & Ncan & $M s / 1$ & Jhdm1d & Scn8a & $C b \times 5$ & Gm12070 & $\begin{array}{c}\text { Ccdc142+ } \\
\text { Mrp/53 }\end{array}$ & Cmpk1 & Ndufb2 & $W f d c 2$ \\
\hline Prox1 & Prrc2c & Ntrk3 & Spire1 & Thsd7a & Dnajc7 & Slc7a14 & Atp $5 f 1$ & Eif3i & Arxes2 & Dalrd3 & Ttr \\
\hline Kcnj6 & lpw & Dusp18 & Rsf1 & Atp8a1 & VIdlr & Hnrnpa2b1 & Rpl10a & Akr1a1 & Pgrmc1 & B3gnt1 & Kcne2 \\
\hline $\begin{array}{l}\text { A130077B15 } \\
\text { Rik }\end{array}$ & Fryl & Ythdf1 & Rock2 & Spp/3 & Galnt/1 & Zmynd11 & Ngfrap1 & Rpsa & $R p / 3$ & Rp/13 & Calm/4 \\
\hline Rnf150 & $\begin{array}{l}\text { 1700025G04 } \\
\text { Rik }\end{array}$ & Elav/3 & Rev3l & Gpd2 & Scn1a & Nell2 & Micu1 & Psmd5 & Coq9 & Fth1 & Tmem72 \\
\hline Setd5 & Kcnma1 & Dscam & Anp32a & Fam160b1 & Larp1 & Trim37 & Atp6v1g1 & $\begin{array}{l}\text { Ndufs5+ } \\
\quad \text { BC002163_d }\end{array}$ & up1 Arpc5 & Tsfm & Steap1 \\
\hline Nhs/2 & St3gal2 & Bod1I & Fam63b & Fam134a & $R b 1 c c 1$ & Sirpa & Ndufs2 & Mrp/15 & Eif3h & Gng10 & Otx2 \\
\hline Tmed9 & Zfp871 & Dusp11 & Agap1 & Gpatch8 & Mgat3 & Cdk14 & $R p / 9$ & Mbp & ВС003965 & Dnm2 & Folr1 \\
\hline $\operatorname{lgsf3}$ & Usp34 & Ap1g1 & Whsc111 & Sbno1 & Cep170 & Dcaf7 & Psmd7 & Flcn & $\begin{array}{l}9530068 E 07 \\
\text { Rik }\end{array}$ & Adrm1 & \\
\hline Crebbp & Ube3a & Rbfox 1 & Slc38a1 & Robo2 & Mtap7d2 & $S f 3 b 1$ & Ppia & Degs1 & Stmn3 & Muted & \\
\hline Cnot6 & Syt7 & Myt1I & Pclo & Elavl1 & Aff4 & Ptpra & Gnb5 & Caly & $C d 9$ & Lrrc45 & \\
\hline Slitrk3 & Bsn & Lrp1b & Nfix & Celf1 & Otub1 & Stxbp1 & Gcsh & Btf3 & Adprh & Por & \\
\hline Tmcc1 & $\mathrm{Cd} 47$ & Cadm1 & Kcna1 & Agtpbp1 & Hlf & Erc2 & Cox5b & $\begin{array}{l}2210016 L 21 \\
\text { Rik }\end{array}$ & $\operatorname{Tmsb} 4 x$ & $P 4 h b$ & \\
\hline Ubn2 & $B c r$ & Ank3 & Hook3 & Zfp238 & Ganab & $\begin{array}{l}\text { Armcx5+ } \\
\text { Gprasp1 }\end{array}$ & Atxn10 & Fam131a & Eif6 & Mgp & \\
\hline Fst/4 & Cacna1e & Ubr4 & Diras2 & Smg1 & Ubqln1 & Ttc3 & Rps3 & $\begin{array}{l}2400001 E 08 \\
\text { Rik }\end{array}$ & Eif1 & Zfp30 & \\
\hline Tab3 & Nav1 & Rasal2 & $\operatorname{Atg} 2 b$ & Sec16a & Nbea & Spna2 & $\operatorname{Prd} 1 \times 1$ & Psmc6 & Dmap1 & Wls & \\
\hline Dusp8 & Mdga2 & Pcdh19 & Slc4a4 & Adnp & Shisa7 & Synj1 & Pgm2 & Ndufb6 & Cct4 & Rps4y2 & \\
\hline Tbr1 & Mdn1 & Nfib & Senp2 & Tmod2 & Rasgrf2 & $\begin{array}{l}\text { Nrp1+ } \\
\quad \text { Mir1903 }\end{array}$ & Gm1821_dup1 & Med28 & Rabac1 & Ezr & \\
\hline
\end{tabular}


Table 2: Genes specifically enriched in retroviral and lentiviral datasets (Continued)

\begin{tabular}{|c|c|c|c|c|c|c|c|c|c|c|}
\hline \multicolumn{5}{|c|}{457 genes enriched in retroviral datasets } & \multicolumn{6}{|c|}{307 genes enriched in lentiviral datasets } \\
\hline Dgkh & Slco3a1 & Dstyk & Irf2bp2 & Ppfia2 & Adrbk2 & Cyfip2 & $\begin{array}{l}\text { A030009H04 } \\
\text { Rik }\end{array}$ & Cox6a1 & $N d n$ & Syt5 \\
\hline Cbfa2t3 & Map3k3 & Snx30 & Ythdc1 & Pbrm1 & Arf3 & Hnrnpu & Ugp2 & Adck3 & Dusp6 & Ctso \\
\hline$D c d c 2 c$ & Tbcel & MIIt3 & Tcerg1 & Nktr & Trim9 & Dlgap1 & Atp6v1h & Sucla2 & $B c / 2 / 1$ & Brp44 \\
\hline Psmd11 & Atxn7/3b & Dpys/2 & Camsap1 & lqgap2 & Syt1 & Cttnbp2 & $\begin{array}{l}1500011 B 03 \\
\text { Rik }\end{array}$ & Polr1d & Aacs & Bex4 \\
\hline Gm17821 & Sorl1 & Sema5a & Bptf & $\mathrm{Gm} 15800$ & Spnb2 & Tcf4 & Stx1a & Sirt2 & $R a b 7$ & Twf2 \\
\hline Foxn3 & Rc3h2 & Nfia & Neto1 & Fut9 & Prkca & Prkcb & Rps9 & Sesn 1 & H3f3a & Vamp3 \\
\hline Eif2c4 & Cdc42bpa & Fry & Foxo1 & Prickle2 & Kcnh1 & Ptk2b & Rps7 & Rp/27a & Cnp & Nudcd2 \\
\hline Pcdh9 & Rasgef1a & Fam171b & Rnf10 & Fam168a & Fam 117b & & Rps25 & Katnb1 & Wdr18 & Lgmn \\
\hline Fam59a & $R c 3 h 1$ & Ccdc82 & $R f x 3$ & Ezh1 & Atrx & & Ndrg4 & Ap1s1 & S100a10 & $A b c b 6$ \\
\hline $\begin{array}{l}\text { E330033B04 } \\
\text { Rik }\end{array}$ & Pds5a & Mga & Pip5k1a & Whsc1 & Nmnat2 & & Hsd17b12 & Tpt1 & Phospho2 & Hgs \\
\hline Itga4 & $\begin{array}{l}\text { C230091D08 } \\
\text { Rik }\end{array}$ & Gm10845 & Fam155a & Gcap14 & S/c24a2 & & Hnrnpk & Tomm22 & Osgep & Chchd6 \\
\hline Zfp488 & Pten & $E m / 5$ & Sv2a & Xpr1 & Olfm1 & & Cfl1 & Rps13 & Id3 & Ubc \\
\hline Rorb & Smg7 & $\begin{array}{l}\text { C330006A16 } \\
\text { Rik }\end{array}$ & Lsamp & Med13I & Aak1 & & Acsbg 1 & $R p / 7$ & Eif3g & Matk \\
\hline MII3 & Prkar2a & Setd2 & Atp2b1 & Lrrfip1 & $R b m 25$ & & Hagh & Pebp1 & Cct6a & Ccdc107 \\
\hline Wipf2 & Odz3 & Gats/2 & Arhgap5 & Brwd1 & Negr1 & & Eif4a3 & $D k k 3$ & Nap1/5 & Hist $1 \mathrm{~h} 2 b c$ \\
\hline $\mathrm{Nr} 2 \mathrm{c} 2$ & $\begin{array}{l}\text { A630089N07 } \\
\text { Rik }\end{array}$ & Rod1 & Trp53inp2 & Atp2b2 & Sort1 & & $A p b b 1$ & Commd8 & Itm2b & Hint2 \\
\hline BC005561 & Mlec & Mycbp2 & Celf2 & Akap6 & Sept3 & & $A b c b 8$ & Plk2 & Hadh & Haghl \\
\hline Kcnq1ot1 & Ablim3 & $1 / d r 2$ & Cacna2d1 & Trrap & Ubr3 & & Tmeff2 & $P f k l$ & $c k b$ & $R a b 1 b$ \\
\hline Rims1 & Slc27a4 & Adam22 & $A b / 2$ & Tnfrsf21 & MII5 & & Wbp2 & Nefl & Atp5g3 & $\begin{array}{l}2410018 M 08 \\
\text { Rik }\end{array}$ \\
\hline
\end{tabular}

SGZ compared with the GCL (Fig. 5B). This group included several genes of potential significance for the development of immature neurons, such as transcription factor Prox1 ( $p=0.03$; Steiner et al., 2008; Lavado et al., 2010; Karalay et al., 2011); cell adhesion molecule Down-Syndrome Cell Adhesion Molecule 1 (Dscam1; $p=0.03$ ) that has a role in neuronal selfavoidance (Matthews et al., 2007); transcripts for Argonaut proteins $(1,3$, and 4 ; eif $2 c 1, p=0.03$; eif2c3, $p=$ 0.03 ; eif2c4, $p=0.01)$ involved in the microRNAinduced silencing complex (Meister, 2013); and roundabout axon guidance receptor homologue 2 (Robo2, $p$ $=0.03)$. The detection of differentially expressed genes by both methods implies that these mRNAs show rapid turnover, whereas upregulated genes by PCR, but not TU tagging, are likely long-lived mRNAs.

As a second comparison, we took the top 50 genes from the retroviral dataset and checked the spatial specificity of their expression with in situ hybridization results in the Allen Brain Atlas (Fig. 6; images were obtained and modified from http://www.brain-map.org). Of this group, $58 \%$ showed the spatial patterns predicted by our RNAseq data (i.e., enhanced expression in the subgranular zone; Fig. 6; a higher expression band occupying the inner border of the GCL), whereas $26 \%$ showed expression in both the subgranular zone and the outer margin, and $16 \%$ were not detected in the subgranular zone in the atlas. Thus, nascent mRNAs identified in the retroviral dataset showed the proper expression pattern with none expressed in regions with only mature granule cells, confirming the spatial specificity of our analysis.

\section{Discussion}

The idea that changes in gene expression underlie functional alterations in synaptic plasticity, and vice versa, is a central tenet of neuronal development and plasticity. However, the methods used to address these questions with appropriate cell type-specific and high- temporal resolution have been limited until recently. Adult-generated newborn neurons provide a good test of such questions as these cells show definitive stages of morphological and synaptic development over the first weeks postmitosis. We adapted the TU-tagging method to compare profiles of nascent mRNAs in immature and mature dentate granule cells.

\section{Limitations of technical approach and comparison to prior results}

Conventional transcriptome studies (e.g., gene expression microarrays, RNAseq) have been successfully used for gene identification in the regulation of cellular differentiation and other processes. These analyses are based on steady-state mRNA (total mRNA or the mature form of transcripts) by quantifying the abundance of transcripts at a given time, and thus such approaches average across both short- and long-lived transcripts. TU tagging (Cleary et al., 2005, Miller et al., 2009, Gay et al., 2013) can complement these approaches by providing high temporal resolution (16-18 $\mathrm{h}$ in our case) as well as cell type-specific resolution. We extended the TU-tagging approach to the intact nervous system to examine nascent mRNA profiles of adult-generated newborn hippocampal granule cells. We used a viral delivery method, which provided superior time resolution (hours rather than days) to transgenic approaches using a floxed UPRT mouse (Gay et al., 2013), and a high degree of certainty that all retrovirus-labeled cells were at the same exact developmental stage. By comparing differential expression between the two viruses, we could also control for any nonspecific changes caused by viral injections. Important to the sensitivity of the TU-tagging approach is the fraction of UPRT ${ }^{+}$cells compared with the total cells in the tissue sample. Thus, in preparing samples for RNAseq, we microdissected the dentate gyrus so that the $\mathrm{URPT}^{+}$fraction was a few percent, similar to the 
A
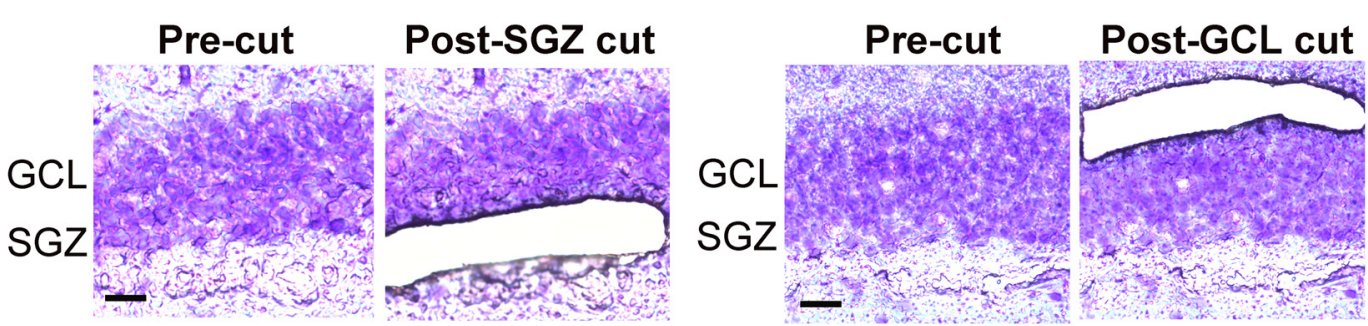

B

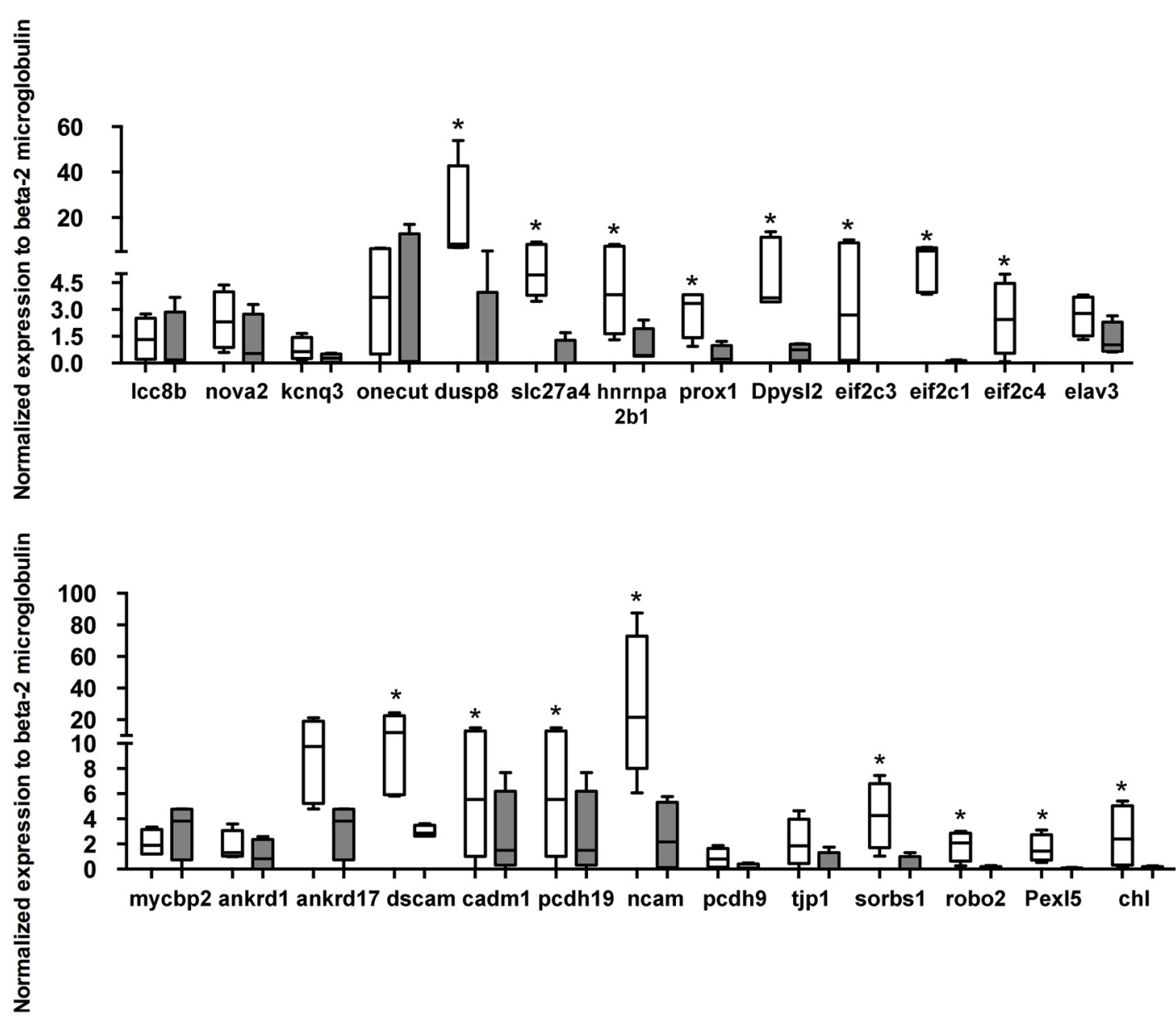

Figure 5. Validation by RT-PCR of TU-tagging target genes in tissue obtained by laser capture microdissection. $\boldsymbol{A}$, Sequential images of SGZ (two left panels) and GCL (right two panels) show the subregion microdissected by laser capture from cresyl violet-stained dentate gyri. Scale bar, $12 \mu \mathrm{m}$. The regions were chosen to show enrichment of immature and mature granule cells, respectively. $\boldsymbol{B}$, qPCR results from laser-captured tissue showed upregulation in the SGZ (white rectangles) compared with the GCL (gray rectangles) in $62 \%$ of the selected genes (16 of 26 genes), mRNA levels were normalized to $\beta_{2}$-microglobulin. $* p<0.05, n=5)$.

fractions in prior TU-tagging experiments in endothelial cells (Gay et al., 2013). In the future, the sensitivity of TU tagging may be further improved using methylthiosulfonate-activated biotin for 4SU-RNA isolation to increase efficiency compared with traditional biotin labeling (Duffy et al., 2015).

Other methods have been developed to examine cell type-specific gene profiling (Tallafuss et al., 2014), with each method having specific advantages. For example, translating ribosome affinity purification (TRAP) has the advantage of isolating mRNAs in the process of trans- lation (Sanz et al., 2009). However, TU tagging has potential advantages compared with TRAP because the latter reflects steady-state RNA levels; whereas, TU tagging detects newly synthesized mRNA depending on 4-TU exposure-the shorter the 4-TU treatment, the closer the analysis approximates the transcriptional rate. This feature is important because fold changes in total RNA do not simply reflect alterations in RNA synthesis, but rather depend on differences in transcript turnover. For example, a 20-fold increase in the synthesis of a long-lived transcript (e.g., half-life, 24 h) will 

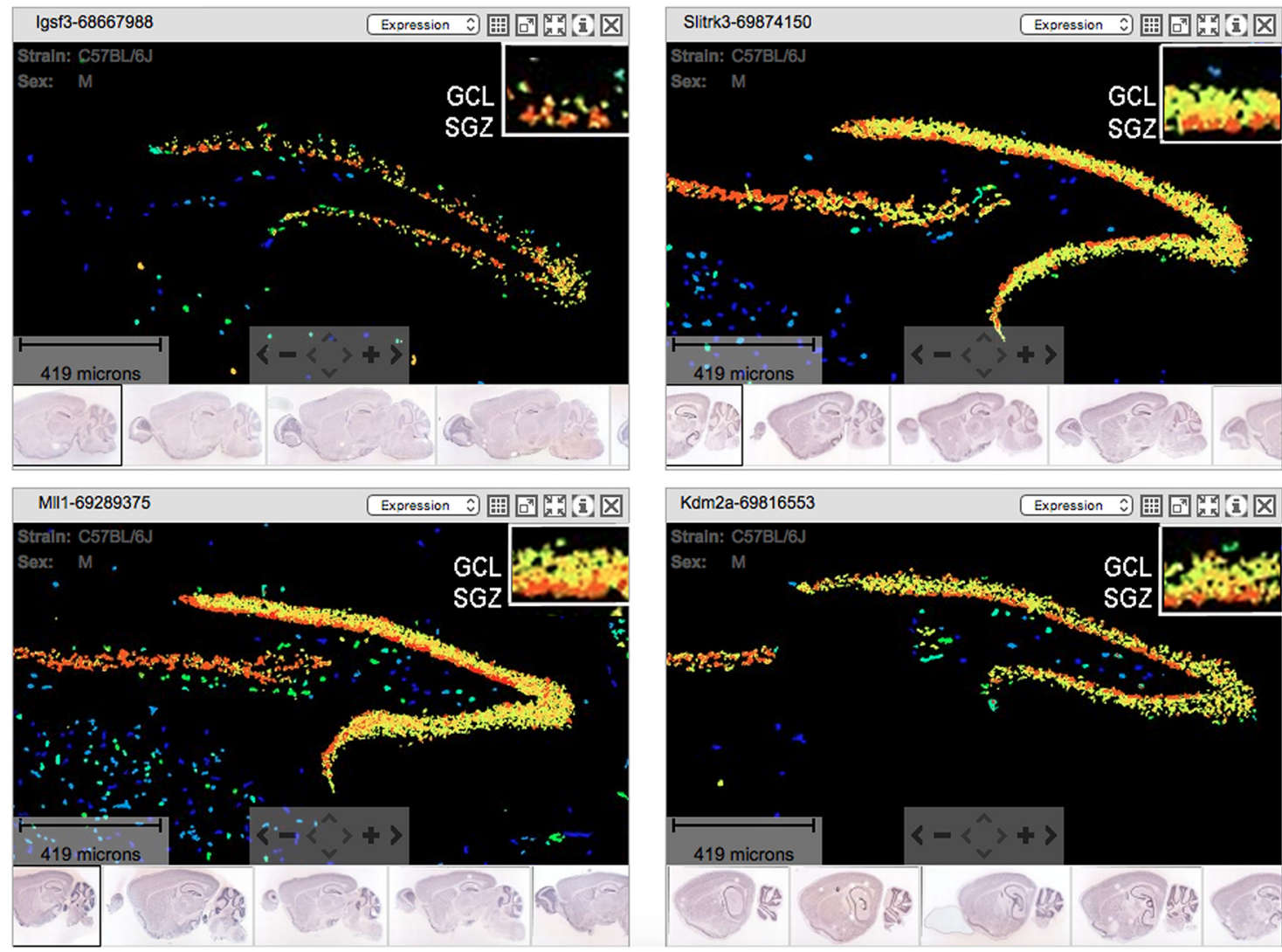

Figure 6. Consistent spatial expression patterns of retroviral enriched genes in mouse SGZ. Representative in situ hybridization images from the Allen Brain Atlas for lgsf3, Slitrk3, MII1, and Kdm2a show SGZ enrichment, which is consistent with our RNAseq data. The expression energy image display highlights the cells with the highest probability of gene expression using a heat map color scale (from low/blue to high/red).

cause only a 1.5-fold increase in total RNA after $1 \mathrm{~h}$ compared with a $>15$-fold increase of a short-lived transcript (e.g., half-life, $30 \mathrm{~min}$ ). Furthermore, TU tagging has the potential to be more sensitive than TRAP because it monitors labeled RNAs directly and also can identify noncoding RNAs.

Cell-specific isolation can also be achieved by mechanical methods such as fluorescence-activated cell sorting (FACS; Wang et al., 2000; Tomomura et al., 2001; Lobo et al., 2006; Cahoy et al., 2008, Bracko et al., 2012) or laser capture (Yao et al., 2005; Rossner et al., 2006; Rohrbeck et al., 2008). For example, laser capture of the subgranular zone in combination with microarrays and in situ hybridization revealed genes associated with interneurons, oligodendrocytes, and vascular cells as well as newborn neurons (Miller et al. 2013). The cell damage and time necessary for cell sorting could alter the quality and quantity of RNA, whereas single-cell laser capture can be contaminated by adjacent cells. Methods are evolving for assessing the transcriptomes of single neurons, but gene coverage remains incomplete in most cases (Macaulay and Voet, 2014). By comparison, our retroviral datasets represent an average of 1000-2000 cells.

\section{Relative gene enrichment in adult-generated immature granule cells compared with mature granule cells}

Microarrays have been used extensively to compare differential gene expression in the brain in vivo (Lein et al., 2004; Arlotta et al., 2005; Yao et al., 2005; Rossner et al., 2006; Miller et al., 2013; Alldred et al., 2012). Such studies have sometimes revealed genes with large fold increases as a result of a treatment or developmental event (Arlotta et al., 2005; Cahoy et al., 2008; Cho et al., 2013). Thus, we were somewhat surprised that, despite the robust statistical measures of gene enrichment in the retroviral and lentiviral datasets, the fold changes were rather modest. Because we directly compared the retroviral and lentiviral datasets, rather than comparing to a diverse background such as whole dentate RNA, our approach does not provide an absolute measure of RNA transcript levels. This may explain in part why we did not see fold changes of great magnitude. It is also possible that changes in mRNA levels underrepresent changes at the protein level. Unfortunately, there is no direct means to obtain sufficient material of adult-generated immature newborn neurons to directly compare mRNA and protein levels. Furthermore, if the "immature" and "mature" stages overlap, from a biological perspective, then fold changes may 
be underestimated. Therefore, fold differences may not be the best criteria for evaluating the significance of individual transcripts.

Because TU tagging identifies nascent transcripts rather than steady-state mRNA levels, it is difficult to compare our results directly with prior transcriptome datasets as each provides distinct information. For example, Bracko et al. (2012) used a FACS approach to compare neural stem cells $\left(\right.$ Sox $\left.2^{+}\right)$with immature neurons $\left(\mathrm{DCX}^{+}\right)$ with microarray methods. Interestingly, none of their top 10 genes in the $\mathrm{DCX}^{+}$population appears in our top 50 enriched genes in the retroviral dataset of immature neurons. This is not particularly surprising, but it does indicate the complementarity of the two approaches. However, there was some overlap in the GO categories, although it is interesting that more synaptically related categories were detected in our dataset, perhaps indicating that these genes were just beginning to be expressed and thus were detected as nascent transcripts rather than increases in steady-state mRNA levels.

\section{Patterns of gene expression in newborn neurons}

Several interesting patterns emerged from the analysis of the nascent RNAs enriched in the immature neurons, indicating a relative increase in turnover of these transcripts. To assess patterns of known signaling pathways in the retroviral dataset, the following three pathways were most prominent from KEGG analysis: long-term potentiation, Wnt signaling, and axon guidance, with several genes enhanced in newborn neurons in each of these pathways. Nascent RNAs enhanced in the long-term potentiation pathway included Grin 2a, Grin 2B, Gria1, CBP, and PKC $\alpha$ and $\beta$, several of which have known functions in newborn neurons. For example, immature adult-born granule cells express functional extrasynaptic AMPA and NMDA receptors before the onset of excitatory synapses (Tashiro et al., 2006; Tronel et al., 2010; SchmidtSalzmann et al., 2014). A function for NMDA receptors in adult neurogenesis has been suggested, although their specific role has been debated (Cameron et al., 1995; Nacher and McEwen, 2006). Grin2a mutants exhibit deficits in the dendritic morphology of a subpopulaton of dentate granule cells specifically located in the subgranular zone (Kannangara et al., 2014). Similarly, the deletion of Grin2b in adult-generated newborn cells did not affect survival, but reduced their dendritic complexity and the pattern separation performance of the transgenic animals (Kheirbek et al., 2012). Enhanced synaptic plasticity of adult-generated granule cells at 1 month postmitosis may also depend on the developmentally regulated expression of Grin2b (Ge et al., 2007).

Several members of the canonical (Frizzled, Axam, $A P C$, Smad3, CBP) and noncanonical (Prickle, Rac, ROCK2, PKC, NFAT) Wnt signaling pathways were also enriched, which is consistent with their roles in multiple stages of adult hippocampal neurogenesis (Varela-Nallar and Inestrosa, 2013; Wu and Hen, 2013). Blocking Wnt signaling in vivo reduced the number of adult-born immature granule cells, and affected hippocampus-dependent spatial and object memory (Lie et al., 2005; Jessberger et al., 2009). Additionally, age-related decline of hippocampal neurogenesis had been associated with dysfunctional Wnt signaling (Miranda et al., 2012). Deletion of $A P C$ in the adult dentate gyrus caused a reduction of both survival and differentiation of newborn granule cells without affecting their proliferation (Imura et al., 2010). Smad3 deficiency decreased the survival of newborn DG cells and abolished LTP in the DG, while LTP induction in the CA1 was evoked correctly, indicating a central role for Smad3 in DG cellular and synaptic plasticity (TapiaGonzález et al., 2013). In the axon guidance pathway, there were 14 genes that were enhanced in the newborn neurons including semaphorins (Sema 5A, Plexin $A$, NRP1) and Slit/Robo (Robo2) signaling. Although little is known about Robo2 signaling in the dentate gyrus, Semaphorin 3 and $5 \mathrm{~A}$ have been implicated in granule cell synaptogenesis (Chédotal et al., 1998; Tran et al., 2009; Duan et al., 2014).

In addition to recognizing patterns of expression, gene profiling can provide novel clues to gene function. Among the top 50 enriched genes, as determined by fold increases, only six have known prior functions in newborn neurons, and six others have functions that are likely to be conserved in newborn neurons. Thus, the majority of enriched genes represent targets for further exploration. Overall, the high spatiotemporal resolution of our approach identified an interesting shift in the pattern of gene expression from synaptogenesis and dendritic/axonal development in newborn/immature neurons to an emphasis on the energy demands of synaptic and dendritic maintenance in mature granule cells. In the future, methods to examine turnover of individual transcripts paired with approaches such as TU tagging should provide a more dynamic view of gene regulation and interaction during neuronal differentiation and maturation.

\section{References}

Aimone JB, Deng W, Gage FH (2011) Resolving new memories: a critical look at the dentate gyrus, adult neurogenesis, and pattern separation. Neuron 70:589-596. CrossRef

Alldred MJ, Duff KE, Ginsberg SD (2012) Microarray analysis of CA1 pyramidal neurons in a mouse model of tauopathy reveals progressive synaptic dysfunction. Neurobiol Dis 45:751-762. CrossRef

Anders S, Pyl PT, Huber W (2015) HTSeq-A Python framework to work with high-throughput sequencing data. Bioinformatics 31: 166-169. CrossRef Medline[Mismatch]

Arlotta P, Molyneaux BJ, Chen J, Inoue J, Kominami R, MacKlis JD (2005) Neuronal subtype-specific genes that control corticospinal motor neuron development in vivo. Neuron 45:207-221. CrossRef Medline

Bracko O, Singer T, Aigner S, Knobloch M, Winner B, Ray J, Clemenson GD, Suh H, Couillard-Despres S, Aigner L, Gage FH, Jessberger $S$ (2012) Gene expression profiling of neural stem cells and their neuronal progeny reveals IGF2 as a regulator of adult hippocampal neurogenesis. J Neurosci 32:3376-3387. CrossRef Medline

Cahoy JD, Emery B, Kaushal A, Foo LC, Zamanian JL, Christopherson KS, Xing Y, Lubischer JL, Krieg PA, Krupenko SA, Thompson WJ, Barres BA (2008) A transcriptome database for astrocytes, neurons, and oligodendrocytes: a new resource for understanding brain development and function. J Neurosci 28:264-278. CrossRef Medline 
Cambronne XA, Shen R, Auer PL, Goodman RH (2012) Capturing microRNA targets using an RNA-induced silencing complex (RISC)-trap approach. Proc Natl Acad Sci U S A 109:2047320478. CrossRef Medline

Cameron HA, McEwen BS, Gould E (1995) Regulation of adult neurogenesis by excitatory input and NMDA receptor activation in the dentate gyrus. J Neurosci 15:4687-4692. Medline

Chédotal A, Del Rio JA, Ruiz M, He Z, Borrell V, de Castro F, Ezan F, Goodman CS, Tessier-Lavigne M, Sotelo C, Soriano E (1998) Semaphorins III and IV repel hippocampal axons via two distinct receptors. Development 125:4313-4323. Medline

Cho H, Proll SC, Szretter KJ, Katze MG, Gale M, Diamond MS (2013) Differential innate immune response programs in neuronal subtypes determine susceptibility to infection in the brain by positivestranded RNA viruses. Nat Med 19:458-464. CrossRef

Cleary MD, Meiering CD, Jan E, Guymon R, Boothroyd JC (2005) Biosynthetic labeling of RNA with uracil phosphoribosyltransferase allows cell-specific microarray analysis of mRNA synthesis and decay. Nat Biotechnol 23:232-237. CrossRef Medline

Clelland CD, Choi M, Romberg C, Clemenson GD, Fragniere A, Tyers $P$, Jessberger S, Saksida LM, Barker RA, Gage FH, Bussey TJ (2009) A functional role for adult hippocampal neurogenesis in spatial pattern separation. Science 325:210-213. CrossRef Medline

Deng W, Aimone JB, Gage FH (2010) New neurons and new memories: how does adult hippocampal neurogenesis affect learning and memory? Nat Rev Neurosci 11:339-350. CrossRef Medline

Duffy EE, Rutenberg-Schoenberg M, Stark CD, Kitchen RR, Gerstein MB, Simon MD. (2015). Tracking distinct RNA populations using efficient and reversible covalent chemistry. Mol Cell 59:858-866. CrossRef Medline

Duan Y, Wang S-HH, Song J, Mironova Y, Ming GL, Kolodkin AL, Giger RJ (2014) Semaphorin 5A inhibits synaptogenesis in early postnatal- and adult-born hippocampal dentate granule cells. Elife 3. CrossRef Medline

Enomoto A, Asai N, Namba T, Wang Y, Kato T, Tanaka M, Tatsumi H, Taya S, Tsuboi D, Kuroda K, Kaneko N, Sawamoto K, Miyamoto R, Jijiwa M, Murakumo Y, Sokabe M, Seki T, Kaibuchi K, Takahashi M (2009) Roles of disrupted-in-schizophrenia 1-interacting protein girdin in postnatal development of the dentate gyrus. Neuron 63:774-787. CrossRef Medline

Fuentealba L, Obernier K, Alvarez-Buylla A (n.d.) Adult neural stem cells bridge their niche. Cell Stem Cell 10:698-708. CrossRef Medline

Gay L, Miller MR, Ventura PB, Devasthali V, Vue Z, Thompson HL, Temple S, Zong H, Cleary MD, Stankunas K, Doe CQ (2013) Mouse TU tagging: a chemical/genetic intersectional method for purifying cell type-specific nascent RNA. Genes Dev 27:98-115. CrossRef Medline

Ge S, Goh ELK, Sailor KA, Kitabatake Y, Ming G, Song H (2006) GABA regulates synaptic integration of newly generated neurons in the adult brain. Nature 439:589-593. CrossRef Medline

Ge S, Yang C-HH, Hsu K-SS, Ming G-LL, Song H (2007) A critical period for enhanced synaptic plasticity in newly generated neurons of the adult brain. Neuron 54:559-566. CrossRef Medline

Gould E, Beylin A, Tanapat P, Reeves A, Shors TJ (1999) Learning enhances adult neurogenesis in the hippocampal formation. Nat Neurosci 2:260-265. CrossRef Medline

Imura T, Wang X, Noda T, Sofroniew M V., Fushiki S (2010) Adenomatous polyposis coli is essential for both neuronal differentiation and maintenance of adult neural stem cells in subventricular zone and hippocampus. Stem Cells 28:2053-2064. CrossRef Medline

Jagasia R, Steib K, Englberger E, Herold S, Faus-Kessler T, Saxe M, Gage FH, Song H, Lie DC (2009) GABA-cAMP response elementbinding protein signaling regulates maturation and survival of newly generated neurons in the adult hippocampus. J Neurosci 29:7966-7977. CrossRef Medline

Jessberger S, Clark RE, Broadbent NJ, Clemenson GD, Consiglio A, Lie DC, Squire LR, Gage FH (2009) Dentate gyrus-specific knock- down of adult neurogenesis impairs spatial and object recognition memory in adult rats. Learn Mem 16:147-154. CrossRef Medline Kannangara TS, Bostrom CA, Ratzlaff A, Thompson L, Cater RM, Gil-Mohapel J, Christie BR (2014) Deletion of the NMDA receptor GluN2A subunit significantly decreases dendritic growth in maturing dentate granule neurons. PLoS One 9:e0103155

Karalay O, Doberauer K, Vadodaria KC, Knobloch M, Berti L, Miquelajauregui A, Schwark M, Jagasia R, Taketo MM, Tarabykin V, Lie DC, Jessberger S (2011) Prospero-related homeobox 1 gene (Prox1) is regulated by canonical Wnt signaling and has a stagespecific role in adult hippocampal neurogenesis. Proc Natl Acad Sci U S A 108:5807-5812. CrossRef Medline

Kheirbek MA, Tannenholz L, Hen R (2012) NR2B-dependent plasticity of adult-born granule cells is necessary for context discrimination. J Neurosci 32:8696-8702. CrossRef Medline

Kuwabara T, Hsieh J, Muotri A, Yeo G, Warashina M, Lie DC, Moore L, Nakashima K, Asashima M, Gage FH (2009) Wnt-mediated activation of NeuroD1 and retro-elements during adult neurogenesis. Nat Neurosci 12:1097-1105.

Lavado A, Lagutin OV, Chow LML, Baker SJ, Oliver G (2010) Prox1 Is required for granule cell maturation and intermediate progenitor maintenance during brain neurogenesis. PLoS Biol 8:e1000460. CrossRef Medline

Lein ES, Zhao X, Gage FH (2004) Defining a molecular atlas of the hippocampus using DNA microarrays and high-throughput in situ hybridization. J Neurosci 24:3879-3889. CrossRef Medline

Lie D-C, Colamarino SA, Song H-J, Désiré L, Mira H, Consiglio A, Lein ES, Jessberger S, Lansford H, Dearie AR, Gage FH (2005) Wnt signalling regulates adult hippocampal neurogenesis. Nature 437: 1370-1375. CrossRef Medline

Lobo MK, Karsten SL, Gray M, Geschwind DH, Yang XW (2006) FACS-array profiling of striatal projection neuron subtypes in juvenile and adult mouse brains. Nat Neurosci 9:443-452. CrossRef Medline

Lois C, Hong EJ, Pease S, Brown EJ, Baltimore D (2002) Germline transmission and tissue-specific expression of transgenes delivered by lentiviral vectors. Science 295:868-872. CrossRef Medline

Luikart BW, Schnell E, Washburn EK, Bensen AL, Tovar KR, Westbrook GL (2011a) Pten knockdown in vivo increases excitatory drive onto dentate granule cells. J Neurosci 31:4345-4354. CrossRef Medline

Luikart BW, Bensen AL, Washburn EK, Perederiy JV, Su KG, Li Y, Kernie SG, Parada LF, Westbrook GL (2011b) MiR-132 mediates the integration of newborn neurons into the adult dentate gyrus. PLoS One 6:e19077. CrossRef Medline

Macaulay IC, Voet T (2014) Single cell genomics: advances and future perspectives. PLoS Genet 10:e1004126. CrossRef Medline

Matthews BJ, Kim ME, Flanagan JJ, Hattori D, Clemens JC, Zipursky SL, Grueber WB (2007) Dendrite self-avoidance is controlled by Dscam. Cell 129:593-604. CrossRef Medline

Meister G (2013) Argonaute proteins: functional insights and emerging roles. Nat Rev Genet 14:447-459. CrossRef Medline

Miller J a, Nathanson J, Franjic D, Shim S, Dalley R a, Shapouri S, Smith K a, Sunkin SM, Bernard A, Bennett JL, Lee C-K, Hawrylycz MJ, Jones AR, Amaral DG, Šestan N, Gage FH, Lein ES (2013) Conserved molecular signatures of neurogenesis in the hippocampal subgranular zone of rodents and primates. Development 140: 4633-4644. CrossRef Medline

Miller MR, Robinson KJ, Cleary MD, Doe CQ (2009) TU-tagging: cell type-specific RNA isolation from intact complex tissues. Nat Methods 6:439-441. CrossRef Medline

Miranda CJ, Braun L, Jiang Y, Hester ME, Zhang L, Riolo M, Wang H, Rao M, Altura RA, Kaspar BK (2012) Aging brain microenvironment decreases hippocampal neurogenesis through Wntmediated survivin signaling. Aging Cell 11:542-552. CrossRef Medline

Mu Y, Zhao C, Gage FH (2011) Dopaminergic modulation of cortical inputs during maturation of adult-born dentate granule cells. J Neurosci 31:4113-4123. 
Nacher J, McEwen BS (2006) The role of N-methyl-D-asparate receptors in neurogenesis. Hippocampus 16:267-270. CrossRef Medline

Nakagawa S, Kim J-E, Lee R, Malberg JE, Chen J, Steffen C, Zhang Y-J, Nestler EJ, Duman RS (2002) Regulation of neurogenesis in adult mouse hippocampus by cAMP and the cAMP response elementbinding protein. J Neurosci 22:3673-3682. Medline Medline

Overstreet-Wadiche LS, Westbrook GL (2006) Functional maturation of adult-generated granule cells. Hippocampus 16:208-215. CrossRef Medline

Rohrbeck A, Neukirchen J, Rosskopf M, Pardillos GG, Geddert H, Schwalen A, Gabbert HE, von Haeseler A, Pitschke G, Schott M, Kronenwett R, Haas R, Rohr U-P (2008) Gene expression profiling for molecular distinction and characterization of laser captured primary lung cancers. J Transl Med 6:69. CrossRef Medline

Rossner MJ, Hirrlinger J, Wichert SP, Boehm C, Newrzella D, Hiemisch H, Eisenhardt G, Stuenkel C, von Ahsen O, Nave K-A (2006) Global transcriptome analysis of genetically identified neurons in the adult cortex. J Neurosci 26:9956-9966. CrossRef Medline

Sahay A, Scobie KN, Hill AS, O'Carroll CM, Kheirbek MA, Burghardt NS, Fenton AA, Dranovsky A, Hen R (2011) Increasing adult hippocampal neurogenesis is sufficient to improve pattern separation. Nature 472:466-470. CrossRef Medline

Sanz E, Yang L, Su T, Morris DR, McKnight GS, Amieux PS (2009) Cell-type-specific isolation of ribosome-associated mRNA from complex tissues. Proc Natl Acad Sci U S A 106:13939-13944. CrossRef Medline

Schmidt-Salzmann C, Li L, Bischofberger J (2014) Functional properties of extrasynaptic AMPA and NMDA receptors during postnatal hippocampal neurogenesis. J Physiol 592:125-140. CrossRef Medline

Scobie KN, Hall BJ, Wilke SA, Klemenhagen KC, Fuji-Kuriyama Y, Ghosh A, Hen R, Sahay A (2009) Krüppel-like factor 9 is necessary for late-phase neuronal maturation in the developing dentate gyrus and during adult hippocampal neurogenesis. J Neurosci 29:98759887. CrossRef Medline

Steiner B, Zurborg S, Hörster H, Fabel K, Kempermann G (2008) Differential $24 \mathrm{~h}$ responsiveness of Prox1-expressing precursor cells in adult hippocampal neurogenesis to physical activity, environmental enrichment, and kainic acid-induced seizures. Neuroscience 154:521-529. CrossRef Medline

Tallafuss A, Washbourne P, Postlethwait J (2014) Temporally and spatially restricted gene expression profiling. Curr Genomics 15: 278-292. CrossRef Medline

Tapia-González S, Muñoz MD, Cuartero MI, Sánchez-Capelo A (2013) Smad3 is required for the survival of proliferative intermediate progenitor cells in the dentate gyrus of adult mice. Cell Commun Signal 11:93. CrossRef Medline
Tashiro A, Sandler VM, Toni N, Zhao C, Gage FH (2006) NMDAreceptor-mediated, cell-specific integration of new neurons in adult dentate gyrus. Nature 442:929-933. CrossRef Medline

Taupin P, Gage FH (2002) Adult neurogenesis and neural stem cells of the central nervous system in mammals. J Neurosci Res 69: 745-749. CrossRef Medline

Tomomura M, Rice DS, Morgan JI, Yuzaki M (2001) Purification of Purkinje cells by fluorescence-activated cell sorting from transgenic mice that express green fluorescent protein. Eur $\mathrm{J}$ Neurosci 14:57-63. Medline

Toni N, Laplagne DA, Zhao C, Lombardi G, Ribak CE, Gage FH, Schinder AF (2008) Neurons born in the adult dentate gyrus form functional synapses with target cells. Nat Neurosci 11:901-907. CrossRef Medline

Tran TS, Rubio ME, Clem RL, Johnson D, Case L, Tessier-Lavigne M, Huganir RL, Ginty DD, Kolodkin AL (2009) Secreted semaphorins control spine distribution and morphogenesis in the postnatal CNS. Nature 462:1065-1069. CrossRef Medline

Trapnell C, Williams BA, Pertea G, Mortazavi A, Kwan G, van Baren MJ, Salzberg SL, Wold BJ, Pachter L (2010) Transcript assembly and quantification by RNA-Seq reveals unannotated transcripts and isoform switching during cell differentiation. Nat Biotechnol 28:511-515. CrossRef Medline

Tronel S, Fabre A, Charrier V, Oliet SHR, Gage FH, Abrous DN (2010) Spatial learning sculpts the dendritic arbor of adult-born hippocampal neurons. Proc Natl Acad Sci U S A 107:7963-7968. CrossRef Medline

Van Praag H, Schinder AF, Christie BR, Toni N, Palmer TD, Gage FH (2002) Functional neurogenesis in the adult hippocampus. Nature 415:1030-1034. CrossRef Medline

Varela-Nallar L, Inestrosa NC (2013) Wnt signaling in the regulation of adult hippocampal neurogenesis. Front Cell Neurosci 7:100. CrossRef Medline

Wang S, Roy NS, Benraiss A, Goldman SA (2000) Promoter-based isolation and fluorescence-activated sorting of mitotic neuronal progenitor cells from the adult mammalian ependymal/subependymal zone. Dev Neurosci 22:167-176. Medline Medline

Wu M V., Hen R (2013) The young and the restless: regulation of adult neurogenesis by wnt signaling. Cell Stem Cell 12:139-140. CrossRef Medline

Yao F, Yu F, Gong L, Taube D, Rao DD, MacKenzie RG (2005) Microarray analysis of fluoro-gold labeled rat dopamine neurons harvested by laser capture microdissection. J Neurosci Methods 143:95-106. CrossRef Medline

Zeiner GM, Cleary MD, Fouts AE, Meiring CD, Mocarski ES, Boothroyd JC (2008) RNA analysis by biosynthetic tagging using 4-thiouracil and uracil phosphoribosyltransferase. Methods Mol Biol 419:135-146. CrossRef Medline

Zhao C, Deng W, Gage FH (2008) Mechanisms and Functional Implications of Adult Neurogenesis. Cell 132:645-660. CrossRef Medline 